\title{
History in the Gene Negotiations Between Molecular and Organismal Anthropology
}

\section{Journal Article}

\section{Author(s):}

Sommer, Marianne

Publication date:

2008

Permanent link:

https://doi.org/10.3929/ethz-b-000011584

Rights / license:

In Copyright - Non-Commercial Use Permitted

Originally published in:

Journal of the History of Biology 41(3), https://doi.org/10.1007/s10739-008-9150-3 


\title{
History in the Gene: Negotiations Between Molecular and Organismal Anthropology
}

\author{
MARIANNE SOMMER \\ ETH Zurich \\ 8092 Zurich \\ Switzerland \\ E-mail: sommer@wiss.gess.ethz.ch
}

\begin{abstract}
In the advertising discourse of human genetic database projects, of genetic ancestry tracing companies, and in popular books on anthropological genetics, what I refer to as the anthropological gene and genome appear as documents of human history, by far surpassing the written record and oral history in scope and accuracy as archives of our past. How did macromolecules become "documents of human evolutionary history"? Historically, molecular anthropology, a term introduced by Emile Zuckerkandl in 1962 to characterize the study of primate phylogeny and human evolution on the molecular level, asserted its claim to the privilege of interpretation regarding hominoid, hominid, and human phylogeny and evolution vis-à-vis other historical sciences such as evolutionary biology, physical anthropology, and paleoanthropology. This process will be discussed on the basis of three key conferences on primate classification and evolution that brought together exponents of the respective fields and that were held in approximately ten-years intervals between the early 1960s and the 1980s. I show how the anthropological gene and genome gained their status as the most fundamental, clean, and direct records of historical information, and how the prioritizing of these epistemic objects was part of a complex involving the objectivity of numbers, logic, and mathematics, the objectivity of machines and instruments, and the objectivity seen to reside in the epistemic objects themselves.
\end{abstract}

Keywords: the history of molecular anthropology, the molecularization of anthropology, human population genetics, human genetic diversity projects, genetic ancestry tracing, paleoanthropology, physical anthropology, evolutionary biology, the anthropological gene, anthropological DNA, the anthropological genome, the political and epistemic values of the classical molecular gene, genetic determinism, molecular clock, human phylogeny, human evolution, human history, human origin, origin stories, primate phylogeny, primate evolution, animal-human boundary, hyman 'races', scientific conferences, Burg Wartenstein symposia, Emile Zuckerkandl, Linus Pauling, Morris Goodman, Vincent Sarich, Allan Wilson, Rebecca Cann, Mark Stoneking, Sherwood Washburn, George Gaylord Simpson, Theodosius Dobzhansky, Ernst Mayr, Milford Wolpoff 
"The parts played by the molecular and the organismic biology come out with extraordinary clarity when viewed against the background of the Science of Man."1

\section{The Anthropological Gene and Genome}

In his book Reflections of Our Past: How Human History is Revealed in Our Genes (2003), anthropologist John H. Relethford defines anthropological genetics in a typical fashion as the use of genetics to reconstruct the history of human populations. Anthropological genetics is seen to hold the answer to such central concerns as who we are and where we come from:

Thinking about ancestry can be extremely frustrating. Most of us know our most immediate ancestors (our parents), most of whom knew their parents, and so on into the past. Over long periods of time, however, this information gets lost, for one reason or the other. Genetics provides a way of uncovering some of this information. Past events - from migration of people from one group to another to changes in population size-may have left a record behind in our genes. Our written and oral histories are incomplete and lack much time depth, but we carry a genetic signature of past events. In this sense, the study of genetics in living people can provide clues to past human history. As we study patterns of genetic variation, we look for such clues that have been preserved in our genes, generation to generation. We can (within limits) learn about the past by studying the present. As noted in the title of this book, genetics provides reflections of our past. This book deals with the search for human history using genetic data. By looking at the current patterns of genetic diversity in humans, we can reconstruct the past. ${ }^{2}$

Relethford ascribes two traits to human genes that will be of concern in this paper: They contain information about genealogy, and they contain history in the sense of evolutionary events. He also privileges the genetic information over "other" historical records due to the supposed time-depth and completeness of that information. To approach this understanding of human nucleotide sequences, I introduce the designations anthropological gene and genome. The expressions refer to the particularity of genes and genomes as those of human organisms. They also refer to human genes and genomes as the epistemological objects in the search for answers to anthropological questions. The anthropological gene and genome are

1 Dobzhansky, 1964, p. 451.

2 Relethford, 2003, p. 9, my emphasis except reflections of our past. 
among the objects of molecular anthropology, the study of primate phylogeny and human evolution on the basis of genomes and proteins. How do anthropological genes relate to other notions of the gene?

As has been abundantly shown, molecular genetics has undermined the reductionist conception of the gene as master molecule in the hierarchy of the central dogma. From the early 1960s, the complexity of gene transcription became increasingly obvious. This put into question the understanding of genes as discrete DNA sequences that contain the information for proteins. The growing knowledge of post-transcription processes further obscured the locus of information. Such insights from molecular biology have rendered the view of the genome as a linear structure ever more problematic. Rather, it appeared as a many-folded system of hierarchies of structural expression and regulation. This raised troubling questions: What is the gene? Where does the information for evolutionary transmission and development reside?

Where the human organism is concerned, the Human Genome Project was initially hailed as the quest for the Holy Grail. However, it eventually confirmed that the sequence of the genome in itself is of little information, that it does not contain life itself. Thus, with the sequencing of the human genome at the outset of the twenty-first century, molecular genetics seems to have reached the end of the century of the gene. Questions of evolution and development demand for an analysis of the genome as the entirety of the cell apparatus of transcription and translation that turns out to be more and more flexible. ${ }^{3}$ Indeed, certain voices in molecular biology have proclaimed a revolution, a paradigm shift from genetics and genomics to post-genomics (functional genomics and proteomics). ${ }^{4}$

It therefore seems that the anthropological gene is a retrograde notion..$^{5}$ It resembles the classical molecular gene in that it is ontologically

${ }^{3}$ For histories of the concept of the gene see for example Keller, 2000; Portin, 1993; Rheinberger and Müller-Wille, 26 October 2004.

${ }^{4}$ For a critical discussion of the "proteomic revolution" see McNally and Glasner, 2007; note that post-genomics is a double entendre in that it refers to a time after the genomics paradigm as well as to a research program that focuses also on levels above the genome in the molecular pathways.

5 In fact, following Francis Collins and his colleagues of the US National Human Genome Research Institute, post-HGP molecular anthropology might more accurately be referred to as (comparative) human genomics. Defending the genomics-paradigm, the understanding of evolutionary genomic variation across species and within the human species is seen as central contribution of genomics to the future of biology, while understanding the relationships between genomics, race and ethnicity, and the consequences of this understanding, would be part of the genomics contribution to society. Ruth McNally and Peter Glasner, 2007, pp. 258-265, observe that this vision of the future of genomics goes along with a continuation of the kinds of genetic determinism characteristic of twentieth-century molecular genetics. 
prioritized and in the sense that its bare sequence appears as the carrier of complex information. However, such perceptions of the gene have also survived in other areas. The idea that genes are responsible for our body, group and individual identity, central behavioral patterns, intelligence, and emotions remains pervasive. ${ }^{6}$ In fact, the persistence of the "genes for" notion is not restricted to "the media," "funding rhetoric," or "the popularization of science." The concept of the sequence of nucleic acids as locus of discrete information retains its potency also for scientists. ${ }^{7}$

The inventor of the term gene, Wilhelm Johannsen (1857-1927), provided a prospective answer to the seeming paradox of the prevalence of the classical (molecular) gene notion: "The 'gene' is nothing but a very applicable little word, easily combined with others, and hence it may be useful as an expression for the 'unit-factors', 'elements' or 'allelomorphs' in the gametes, demonstrated by modern Mendelian researches." 8 The gene may be nothing but a little word, but even a hundred years after Johannsen's acute observation, it remains of applicable, of epistemological value in some areas. ${ }^{9}$ It also remains of political value. ${ }^{10}$ In the following, I will explore how this applies for molecular anthropology, where it is indeed the variation in the very succession of nucleotides in DNA sections that is informative. The genome as sequence of nucleotides also carries great symbolic meaning. The anthropological gene and genome played a political role in the formation of molecular anthropology vis-à-vis more traditional anthropological fields. The anthropological gene and genome were and are claimed as the locus of the most fundamental information for the establishment of our place in primate systematics.

However, the kind of information the anthropological gene and genome are supposed to carry is special in that it can be of a narrative nature. The anthropological gene is then understood as a record of past events. It is therefore performed in the semantic field of historical reconstruction. In the quotation from Relethford above, the insights from molecular anthropology are presented as a seamless extension of the individual's family history into the deeper past and finally to the

${ }^{6}$ For a history of genetic determinism in the context of the history of (molecular) genetics see Keller, 1992.

7 Stotz, et al., 2004, found in their empirical study that the classical molecular notion of the gene as a stretch of DNA (sequence) that codes for a polypeptide chain continues to be central in biology.

8 Johannsen, 1911, p. 132.

9 On the epistemic value of the classical gene notion see Waters, 2004.

${ }^{10}$ Michael Dietrich, 2000, argues that the problem of the gene persists not because of its epistemic value but because of its political value in struggles over scientific authority. 
evolutionary history of humankind at large. Genes take over where oral history and written records break down. I shall return to this contemporary phenomenon. Before doing so, I aim at an understanding of how the anthropological gene became the most authoritative level for phylogenetic reconstruction and a document of human history in the first place. For an illumination of this process, the negotiations over the privilege of interpretation regarding hominoid, hominid, and human evolution prove particularly revealing. I therefore provide an analysis of instantiations of these negotiations between molecular anthropology, evolutionary biology, and physical anthropology and paleoanthropology. The anthropological gene and genome therein emerge as part of a rhetorical complex involving the objectivity of numbers, logic, and mathematics, the objectivity of machines and instruments, and the objectivity seen to reside in the epistemic objects themselves.

In what follows, I thus reconstruct an episodic history of molecular anthropology in contact with other approaches to anthropological questions through three key conferences on primate classification and evolution. These platforms of encounter will serve to analyze how the assumption of a natural phylogeny preserved in DNA and proteins was negotiated, and how these molecules became inscribed with evolutionary history. The first event took place in 1962, when the very term molecular anthropology was coined. As the term suggests, molecular anthropology does not predate the molecularization of biology driven by the application of physical and chemical methods and instruments in the 1950s and 1960s. ${ }^{11}$ At the time of the conference, technologies for protein sequencing had only recently become available, and the genetic code had just begun to be "deciphered." 12 That the establishment of primate classifications and

11 According to Edward Yoxen, 1982, molecular biology arose from a complex of factors: a new conception of life reduced to the molecular level that was reductionist and informational, having its beginnings in genetics (theoretical population genetics); a boom in the experimental physical sciences after WWI and increasingly during and after WWII; a reorganization of science funding during this period, with the Rockefeller Foundation (and later the NSF) funding new areas of life sciences research that fit the criteria of the hard sciences; the new post-WWII media such as television that allowed to broadcast the molecular approach to the secrets of life. Hans-Jörg Rheinberger, 1995, p. 2, emphasizes the importance of new technologies of visualization in the study of organisms and the use of new model organisms (for detailed histories of molecular biology see de Chadarevian, 2002; Judson, 1996 (1979); Kay, 1993, 2000; Olby, 1994 (1974)).

12 The English biochemist Frederick Sanger (b. 1918) succeeded in protein sequencing in the late 1940s, and in DNA sequencing in the 1960s, developing improved techniques in the 1970s. The American biochemist Marshall Nirenberg (b. 1927) and the German biochemist Heinrich Matthaei (b. 1929) "deciphered" the first codon in 1961, and within five years the basics of the genetic code were revealed (Judson, 1992, pp. 52-54, 59-60). 
phylogenies initially built on protein analyses was therefore due to the state of the technological art rather than the prioritization of proteins over genes. To the contrary; as the discussion of the conference will show, from the start the idea that the closer to the gene the more reliable was the analysis, characterized the molecular approaches. Some of the early molecular anthropologists viewed the nucleotide sequences of genes as the key to the natural order of the primates. Least "contaminated" by higher order interaction and environmental "distortion," they appeared to be the carrier of evolutionary history in the raw.

Already in 1962, primate classifications and phylogenies arrived at through the comparison of macromolecules challenged those based on fossil remains and recent organisms. However, the main incentive for the 1962 conference had been to arrive at a better integration of anthropology into the evolutionary synthesis. A reform of primate classification and phylogeny under the new systematics was still under way. It appears that at the conference under concern, the awareness of the organismic population geneticists present was raised to the threat molecular anthropology posited to this endeavor. While they advocated a populational approach to the fossil record, others introduced the possibility of the superiority of macromolecules over morphological characters for phylogenetic analysis. The arguments made in favor of "the gene" are among those still current: The molecules involved in DNA replication and protein synthesis span the entire living kingdom; the nucleotide sequence of the gene is discrete; the number of nucleotides in a gene is large; nucleotides are quantitatively comparable across genes; it is possible to estimate dates of divergence for groups without a fossil record; and finally, gene sequences are immediate records of heritable changes. ${ }^{13}$

This kind of reasoning was well underway by 1975, the year of my second horizontal section. This conference again brought together different approaches to primate classification and evolution. However, molecular anthropology was at the center of interests, and some of its results demanded a radical reconceptualization of primate phylogeny. One argument for priority of these results over the analysis of fossils was the claim that traditional physical anthropology and paleoanthropology were subjective and ideology-ridden. In contrast, molecular anthropology was seen as characterized by rigorous mathematical logic and technology-driven quantitative approaches. The supposed valueneutrality and objectivity of molecular anthropology were also

13 See for example Fitch, 1982, p. 1135. 
associated with the fundamental nature of the anthropological gene and genome itself. Correspondingly, the techniques that promised the most direct approach to the most basic level of analysis had gained the highest authority among the molecular methods. Amino acid sequencing dominated, and even the unmediated study of DNA had come into reach. This meant direct access to the molecule that documented our evolutionary history. The prospect was linked to the hope that molecular anthropology would be able to tackle intra-human phylogeny. At the same time, troubling uncertainties remained, and in particular the molecular clock hypothesis was discussed controversially. Of particular interest in the context of this paper is the unstated paradox that emerged when the notion of molecular clocks was combined with the neutral theory of molecular evolution. The anthropological gene and genome figured as stochastic clock for measuring the lapse of time since the separation of lineages. At the same time, it was inscribed with historical meaning.

The advent of recombinant DNA technologies in the 1970s made possible the isolation, cloning and detailed analysis of specific DNA sequences. Indeed, the new technologies and new objects such as mitochondrial DNA eventually did make it feasible to approach such recent diversification events as those within Homo sapiens. The third conference discussed documents this very moment at the root of the proliferation of intra-human "family trees." At the 1987 conference, modern human origins and dispersal were the main concern. Around these questions, new alliances were formed between the different approaches. The evolutionary narratives that emerged were supported by diverse evidence, molecular and other. Although a look at the molecular studies presented at this conference will bring us much closer to Relethford's notion of anthropological genetics as providing reflections of our past, it will also become clear that the stories read from the DNA had been previously available.

In the time following this conference, the innovation and marketing of laboratory inventory, such as PCR technology (1987), rendered the comparative analyses of DNA sequences less money and time consuming. The gaining of ground of molecular systematics manifested itself in the establishment of laboratories at such strongholds of tradition as the leading museums (Smithsonian Institution, the American Museum of Natural History, the British Museum, the Field Museum, and natural history museums in Stockholm, Munich, and Madrid). Obviously, museums were the places where specimens abounded for molecular analysis by means of DNA sequencers, oligonucleotide synthesizers, PCR amplification machines, ultracentrifuges, and 
spectrophotometers. But also the dream expressed at the 1987 conference of tapping the information stored in the gene pools of living humans "with a battery of population specific polymorphisms" had come true. By then, the anthropological gene and genome had long been charged with authority and inscribed with evolutionary history.

\section{Proteins as Cleaner Material for Phyletic Investigations than Morphological Characters: The Burg Wartenstein Symposium of 1962}

In 1962, the Austrian-born American biologist Emile Zuckerkandl (b. 1922) introduced the term molecular anthropology to characterize the study of primate phylogeny and human evolution through the genetic information contained in proteins and polynucleotides. The same year, his cooperation with the American physical chemist Linus Pauling (1901-94) at the California Institute of Technology resulted in a paper on the relative similarities of hemoglobin amino acid sequences in humans, the gorilla, the horse, and fish. ${ }^{14}$ They laid the basis of the hypothesis later subsumed under the expression molecular evolutionary clock. ${ }^{15}$ It assumed that proteins, like organisms, evolve, and that two groups of organisms that at one point shared a common ancestor would at that point also have shared a molecular makeup. After separation, an ancestral molecule would have evolved independently in the two lines of decent while maintaining structural homologies. Zuckerkandl and Pauling arrived at a rate of evolution from the horse-human alphachain differences and the estimated geological age of their common ancestor. They further supposed that amino acid substitutions in the hemoglobin chains that were not eliminated by natural selection fluctuated around this mean also in other species. On this basis, they came up with a date of divergence for the human and gorilla lines of about eleven million years. This estimate was at the lower end of the then current ones by paleontologists, the higher end of which was about 35 million years.

The occasion at which the term molecular anthropology was coined was the Burg Wartenstein symposium of 1962. Both Michael Dietrich and Gregory Morgan have identified this event as an important

${ }^{14}$ Zuckerkandl and Pauling, 1962, particularly pp. 198-206. Gregory Morgan, 1998, has shown how Pauling's concern about the threat of nuclear fallout to humans motivated his research in molecular biology and led to the conceptual link between molecular disease and molecular evolution as evidenced in this paper.

15 Zuckerkandl and Pauling, 1965a, p. 148. 
platform of negotiation between evolutionary biology and molecular evolution. ${ }^{16}$ It is the starting point of my analysis, because of its focus on human classification and evolution. The experimental practices thus named can be traced back to the immunological studies of the American-British bacteriologist George H. Nuttall (1862-1937) in the early twentieth century. ${ }^{17}$ However, this Burg Wartenstein symposium and the one in 1975 on progress in molecular anthropology indicated some consolidation of the molecular approaches to anthropological questions. Burg Wartenstein in Austria had been refurnished as a conference center for the Wenner-Gren Foundation for Anthropological Research of New York, worldwide the only foundation solely for anthropology (inaugurated in 1951 out of Viking Fund Inc. from 1941). The castle had been damaged during WWII, and bought for Axel L. Wenner-Gren (1881-1961) in 1957. It had been Wenner-Gren's intention to create a center for scientific activities on an international and interdisciplinary basis: "Conferences and symposia are to be projected whenever possible and practicable on interdisciplinary problems where anthropology could act as the integrating factor.",18

The internationality of the 1962-symposium on classification and human evolution was modest, with the United States and Great Britain taking the lead, followed by Switzerland, and with the addition of Louis Leakey (1903-72) from Kenya. It nonetheless seems that nothing could have fit Wenner-Gren's wish better than the layout of this conference with its multiple approaches to anthropological issues. Indeed, the scientific motivation for the conference had been the perception that anthropology had only insufficiently been brought under the paradigm of the evolutionary synthesis. The attempt to remedy this situation had started two years earlier at a meeting of the American Institute of Human Paleontology, which had been followed by another meeting at the Wenner-Gren Foundation, and a symposium at the American Anthropological Association meetings in Philadelphia in 1961. However, despite these premises, the conference turned out to be less integrative than expected.

Central figure in the endeavor to integrate anthropology and synthetic evolutionary biology was Sherwood L. Washburn (1911-2002), who organized the Burg Wartenstein conference and edited the

\footnotetext{
16 Dietrich, 1998, pp. 91-95; Morgan, 1998, pp. 174-175.

17 Nuttall, 1904.

18 In Haury, 1963, p. 90; on the Burg Wartenstein program see also "Toward Discovery by Communication: The New Conference Center at Burg Wartenstein,” 1960.
} 
conference volume. ${ }^{19}$ Washburn pioneered the new physical anthropology as a combination of functional, behavioral, and populational approaches to human biocultural history. ${ }^{20}$ Variation within populations instead of typological classification was seen as central for an understanding of the processes of evolutionary change. Theory, and experimentally verifiable hypothesis, set the analytical framework. Measurements were only one among many techniques applied to particular problems, to which the molecular approach would be added in the 1960s. In 1958, Washburn had accepted the position of a professor of anthropology at the University of California, Berkeley, where he took on the role as the most important scientist for the institutionalization and canonization of post-WWII physical anthropology in the United States. ${ }^{21}$

In accordance with Washburn's program, the Burg Wartenstein symposium he organized in 1962 was dominated by the architects of the evolutionary synthesis. Correspondingly, the resulting volume was framed by George Gaylord Simpson's opening chapter (1902-84; then Harvard University) and the two closing ones by Ernst Mayr (1904-2005; then Harvard University) and Theodosius Dobzhansky (1900-75; then Rockefeller Institute). As Simpson made clear at the outset, the main concern was to bring order into hominid classification: "It is notorious that hominid nomenclature, particularly, has become chaotic." 22 The sharp comment was aimed at physical anthropology that had not followed the taxonomic practices from zoology but created far too many taxa for the few fossils found. This was to be remedied by the populational approach. With an understanding of populations as polytypic, the family Hominidae could be simplified to two genera, Australopithecus and Homo. Simpson also found fault with physical anthropology for having generated too many taxa within Hominoidea. Rather, he accepted what he called the Dryopithecine complex as the pool from which both the line leading to chimp and gorilla and that leading to humans had emerged. This subsumed fossils from the Miocene and Pliocene of Africa, Europe, and Asia, such as Dryopithecus, Ramapithecus, and Kenyapithecus (Figure 1).

As the structure of the conference volume Classification and Human Evolution (1963) suggests, the three chapters on molecular anthropology

19 Washburn had already organized and published the Burg Wartenstein conference on the social life of early man in 1959, which had included primate field studies as well as papers on human evolution (Washburn, 1961, 1963).

20 Washburn, 1951, 1952.

${ }^{21}$ Haraway, 1988, pp. 216-227; Spencer, 1982; Washburn, 1983.

${ }^{22}$ Simpson, 1963, p. 5. 


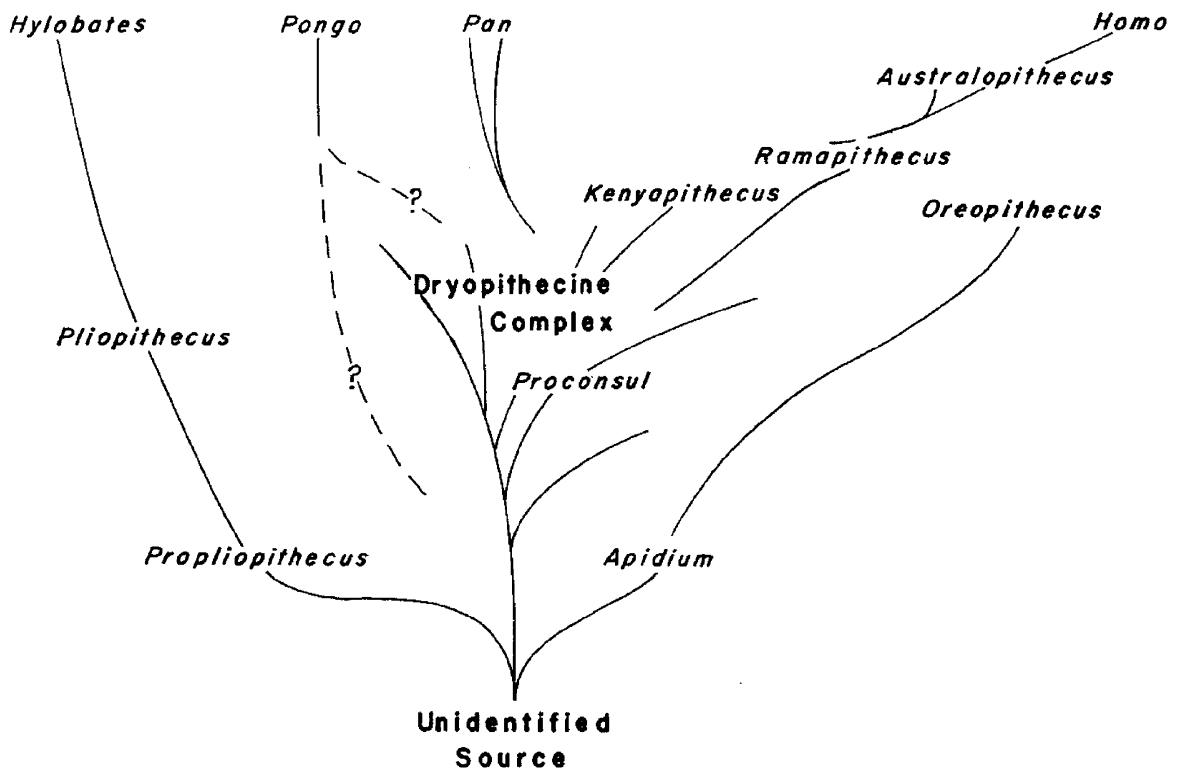

Figure 1. Phylogeny of the Hominidea, showing the family Hominidae (comprising the genus Homo and Australopithecus) and the subfamily Ponginae (of the family Pongidae, and comprising the genus Pan and Pongo) to have arisen from the Dryopithecus complex, with Ramapithecus and Kenyapithecus situated already towards the hominid line (the younger Ramapithecus had been dated to 14 million years); from Simpson, George Gaylord 1963. "The Meaning of Taxonomic Statements." In Classification and Human Evolution, edited by Washburn, Sherwood L. Chicago: Aldine, p. 27, Figure 6. Viking Fund Publications in Anthropology No. 37, New York, NY, by permission of the Wenner-Gren Foundation for Anthropological Research, Inc., New York, NY.

were part of what needed to be framed within the larger paradigm. Simpson regarded studies of serum proteins and chromosomes as helpful in the clarification of the classification conundrum. He for example took them as the basis for lumping the gorilla and the chimpanzee into one genus. However, he qualified their results with respect to humans. Even granting that biochemically humans and chimpanzees might be very similar, humans were morphologically and adaptively radically different from apes (Figure 2). Accordingly, Simpson maintained an early separation of the hominid and anthropoid lines and the taxonomic difference of African apes and humans on the family level. To this belief he appropriated the molecular results of Zuckerhandl and Morris Goodman (b. 1925):

Seemingly contradictory evidence (e.g. that of the haemoglobins as reported by Zuckerkandl in this book) indicates merely that in certain characters Homo and its allies retain ancestral resemblances 


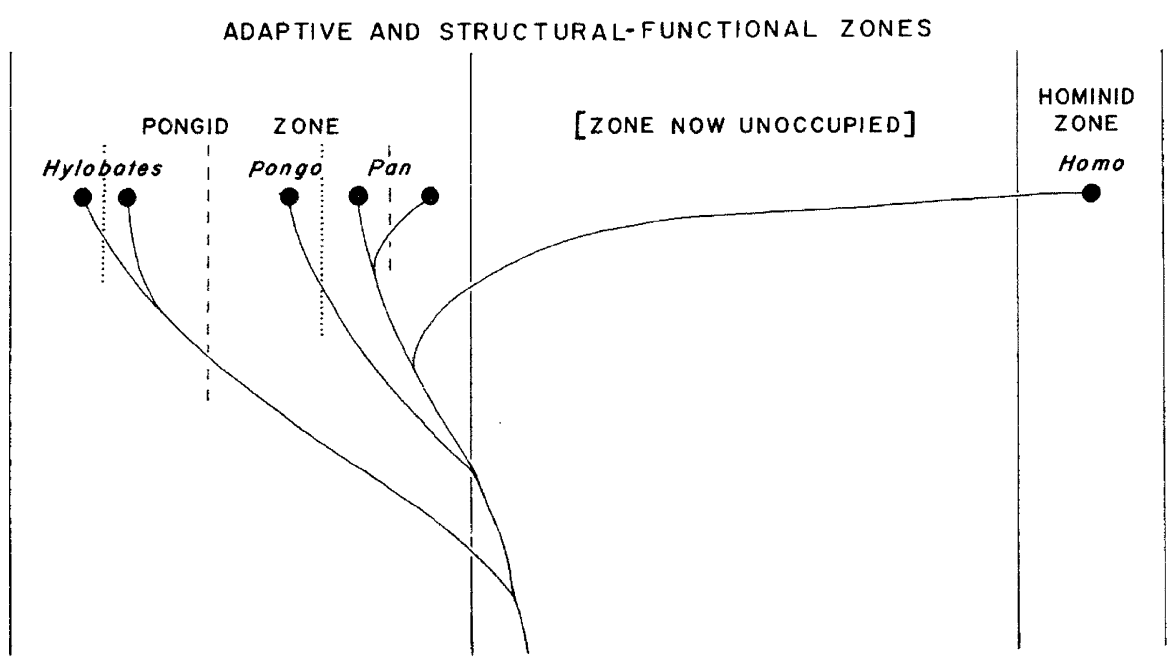

Figure 2. Dendrogram of affinities of recent hominoids relative to their radiation into adaptive-structural-functional zones; the horizontal distance between two taxa among other things indicates behavioral distance (grade), and the vertical distance of two taxa from their point of separation indicates time of lineage split (clade) - for Simpson, both had to be taken into account for classification; from Simpson, George Gaylord 1963. "The Meaning of Taxonomic Statements." In Classification and Human Evolution, edited by Washburn, Sherwood L. Chicago: Aldine, p. 26, Figure 5. Viking Fund Publications in Anthropology No. 37, New York, NY, by permission of the Wenner-Gren Foundation for Anthropological Research, Inc., New York, NY.

and that these are not the characters involved in their otherwise radical divergence - a common and indeed universal phenomenon of evolution. ${ }^{23}$

Even before the careful reader, who peruses the volume from front to back, actually meets with the papers by Zuckerkandl and Goodman, Simpson devalues their results by his claim that macromolecules were simply not the right objects on which to base phylogenies.

The results presented by the biochemist Goodman (Wayne State University School of Medicine, Detroit, Michigan) in his contribution to the conference volume were those of his pioneering experimentation on the immunoreactivity of albumin among primates. ${ }^{24}$ Like Simpson, Goodman felt that physical anthropology and paleontology lacked objectivity. He did not see the solution in a more rigorous theoretical approach to taxonomy, however. Rather, he appealed to an objectivity

${ }^{23}$ Simpson, 1963, p. 25.

${ }^{24}$ Goodman, 1960, 1962; Goodman, et al., 1960. 
that seemed to reside inside new technologies and the gene itself. $\mathrm{He}$ drew on recent research in protein chemistry and genetics that showed that there was a close correspondence between the structural specificity of proteins and the code of information in genetic material. This rendered the comparison of proteins promising for systematics: "Hence by utilizing some of the newer biochemical and serological methods for studying the structural specificity of proteins it is possible to ascertain the genetical affinities of contemporary organisms with a reasonable degree of objectivity." 25

Goodman had studied serum proteins of primates by twodimensional starch-gel electrophoresis and agar gel precipitin method. The results suggested that the chimpanzee and the gorilla were the closest human relatives (possibly in this order), followed by the orangutan, and finally the gibbon. This was congruent with received wisdom from morphology. However, the molecular similarity between humans and African apes led Goodman to propose a new taxonomy with revolutionary potential. He moved the chimpanzee and the gorilla to the family Hominidae, with only the orangutan left to represent the Pongidae. He thus opposed Simpson. His taxonomy made it clear that classification should reflect (molecular and morphological) similarity and divergence time (i.e. clade), but that it should not incorporate "less rigorous" criteria such as rate of structural-functional evolution due to entering new adaptive niches (i.e. grade) (Figure 3).

This new systematics provoked skepticism towards the technologies of molecular anthropology rather than a rethinking of taxonomy. Even though Goodman did not question established phylogenies in the more radical aspect of times of divergence. Rather, to account for the little differences on the molecular level between African apes and humans, Goodman assumed a slowdown of protein evolution in the course of anagenetic progress. He saw the complexity of higher organisms as the result of more integrated informational contents of genome sections. As complexity had increased in the course of evolution, the possibility of proteins to vary in their specificity within the species had decreased. Therefore, in the beginning of phylogenesis, many changes could have been accumulated in proteins, whereas with evolutionary progress, molecular evolution would have slowed down. Furthermore, once the placental sage was reached, gestation time increased with grades, which heightened constraints on protein variability due to the necessity for mother-infant immunological compatibility. There thus seemed to exist

25 Goodman, 1963, p. 205. 


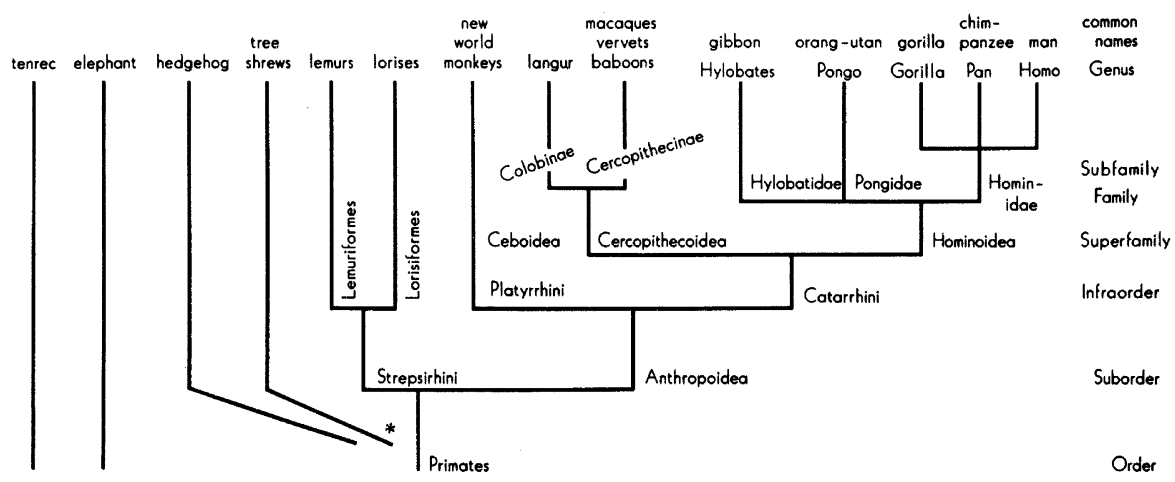

Figure 3. Morris Goodman's classification based on serological reactions (two-dimensional starch gel electrophoresis and agar gel precipitin technique); from Goodman, Morris 1963. "Man's Place in the Phylogeny of the Primates as Reflected in Serum Proteins." In Classification and Human Evolution, edited by Washburn, Sherwood L. Chicago: Aldine, p. 230, Figure 5. Viking Fund Publications in Anthropology No. 37, New York, NY, by permission of the Wenner-Gren Foundation for Anthropological Research, Inc., New York, NY.

paradoxical selective pressures on any anagenetically advancing species, favoring both, molecular conservatism for inward stability and heterozygosity for outward adaptability.

Goodman saw the solution in the fact that proteins remained stable over considerable differences in primary structure (they maintained their folding and function). Additionally, he thought that the prenatal molecular makeup was kept conservative, but that more flexibility was allowed after birth. As a consequence, human albumin, which was synthesized early in fetal life, showed little variance to the chimpanzee and the gorilla proteins. On the other hand, other blood proteins such as globulin were synthesized postnatally and therefore showed greater differences between the living Hominoidea. This theory accounted for the lack of agreement between blood protein studies. It also opened up a space for reconciling the minimal molecular differences between the African apes and humans with the impression of great morphological differences. It was amenable to the assumption of long independent evolutionary lines, and, as in the case of Simpson, to a taxonomic separation on the level of the family.

Goodman's conclusion of a close evolutionary relationship between humans, the chimpanzee, and the gorilla gained support from morphological comparisons of chromosomes, which showed the closest 
similarity to be between Homo and $\mathrm{Pan} .{ }^{26}$ However, the real challenge to existing phylogenies came from Zuckerkandl's paper (then at Caltech). Zuckerkandl showed more confidence in molecules when it came to the question of whether the results from the new technologies of molecular anthropology or from the traditional morphological approaches should provide the framework for hominoid phylogeny: "There are, however, in living matter two types of compounds that are far more informative than any other characters, namely certain kinds of nucleic acids and their products, the proteins. These are the specific constituents just mentioned of which morphological characteristics are an overall expression." 27

Zuckerkandl discussed the three major ways in which these most informative characters could be analyzed. The method applied by Goodman of comparing homologous proteins by immunological techniques was the most powerful in that it was fast. Protein amino acids could also be sequenced. ${ }^{28}$ Or so-called fingerprinting could be carried out. ${ }^{29}$ Zuckerkandl had been involved in fingerprinting for hemoglobin to compare humans and the great apes. The patterns for human, chimpanzee, and gorilla hemoglobin had turned out indistinguishable. Only the orangutan hemoglobin provided a slightly different pattern. ${ }^{30}$ However, Zuckerkandl favored full amino acid sequencing of proteins, for which a combination of the available methods was necessary. Protein sequence analysis provided "[...] the most precise and least ambiguous insights into evolutionary relationships and into some of the fundamental mechanisms of evolution." 31 The method would only be trumped by genetic sequencing that was not yet technically available. In Zuckerkandl's line of reasoning, an analysis of the structural gene, understood as that segment of DNA that contained the information for one polypeptide chain, would be the most informative.

The sequencing of proteins as gene proxies looked at point mutations that had been fixated in the genome. Zuckerkandl considered this kind of change the most commonly retained in structural genes and in proteins during evolution (rather than terminal growth, splitting, losing or

${ }^{26}$ Klinger et al., 1963.

27 Zuckerkandl, 1963, p. 243.

28 This was done by X-ray diffraction, or stepwise chemical degradation, or breakdown by a wide array of proteolytic enzymes, and comparison of the pieces.

29 This consisted in the application of a highly specific proteolytic enzyme to a protein and two-dimensional spreading of the resulting fragments over a piece of filter-paper by a combination of electrophoresis and chromatography to obtain a specific pattern.

30 Zuckerkandl, et al., 1960.

31 Zuckerkandl, 1963, p. 244. 
gaining sequences and duplication). However, the protein was slightly less authentic than DNA because the genetic code reduced the possibilities for a point mutation in DNA to result in an amino acid substitution. ${ }^{32}$ New genes/proteins, on the other hand, were most likely to arise through duplication. ${ }^{33}$ Zuckerkandl agreed with Goodman that fixations of point mutations occurred at different frequencies in different areas of DNA, due to physico-chemical properties, to differential selective pressure, to variable length, and to mutation tolerance. Even within one protein, areas would differ in their tolerance to change. There might be (nearly) indifferent substitutions that were selectively neutral. Substitutions in regions that altered the interchain and intermolecular relations would be less frequent. However, because these did not have an all-or-nothing effect with regard to function, they would be more likely than mutations in areas essential for the protein's function as a whole. The latter kind of mutation would be fixated with the least frequency. It was nonetheless possible, as exemplified by the sickle cell condition, which was a point mutation that changed the functionality, but was retained because otherwise selectively positive.

The variation in mutation rates between protein regions, between non-homologous proteins, and between homologous proteins in different lineages was a paramount problem with regard to the molecular approach to anthropology and evolution. It was therefore a point discussed by a restricted committee that besides the molecular specialists included Dobzhansky, Mayr, and Simpson. The discussion on the pros and cons of the molecular approach was later continued in the Burg Wartenstein plenum. We know that this happened, and can guess what the events might have been like, because Zuckerkandl took the arguments up in his contribution to the conference volume. Unfortunately, he does not always indicate which position was taken by which participant.

One consequence of the rate problem was the question of how quantity should be translated into degrees of similarity/difference between organisms. Should the number of differences in amino acids between proteins in different lineages be related to the maximum amino acid changes a polypeptide may tolerate before losing its functionality, or to the number of amino acids it contained? Furthermore, back or repeated mutation at one site did not leave traces, a problem increased for phylogenetically more distant taxa. Unrelated to the problem of

\footnotetext{
32 Zuckerkandl here drew on Nirenberg and Matthaei, 1962.

${ }^{33}$ By translocation and subjection to another regulator gene for example (Jacob and Monod, 1961).
} 
interpreting molecular differences, but possibly most importantly for some participants, protein analysis could not determine whether a gene pool was open or closed. It was therefore difficult to defend its relevance to an understanding of speciation. Secondly, evolutionary trends would be visible on the level of organisms only. Evolutionary trends were the prerogative of fossils, which were the records of historical developments. The knowledge available on the molecular level seemed therefore further limited because of the lack of proteins from fossils, but their availability was seen as a future possibility.

In conclusion, Zuckerkandl seems to have unmitigatedly reproduced the synthesists' stance. Not only was advanced technology needed for the sequencing of many proteins in many organisms, but for the larger picture of evolution, these molecular analyses would have to be combined with all other levels of analysis up to human psychology:

[...] when the molecular, supra-molecular, cellular, tissular, organic, systemic, individual, and further the ecological, sociological and psychological levels are considered, it appears that the key to the determinism of evolutionary trends is found at the higher levels of integration more than at the lower ones. This appears to be so because natural selection acts on functional characters and functions are carried out by coordinated wholes. ${ }^{34}$

That results from molecular anthropology made sense only in the context of "higher-order" evidence was certainly true for phylogenies that included divergence times. While degrees of similarity could be elicited in molecular biology laboratories alone, other sources were necessary for the establishment of distances in time. As we have seen, in their work on amino acid substitution rates, Zuckerkandl and Pauling had depended on a date from paleontology to calculate the mutation rate. ${ }^{35}$ Zuckerkandl therefore conceded that molecular phylogeny was merely complementary to non-molecular kinds of evidence at least in this respect: "They [sequence comparisons] furnish interesting indications, but cannot be relied upon in the absence of confirmatory evidence from a different source." 36

In the consideration of the pros of the new methods for the assessment of degrees of similarity/difference between organisms, analysis of primary structure (amino acid sequence), secondary and tertiary structure (folding and special arrangement), and higher molecular units, such

34 Zuckerkandl, 1963, p. 258.

35 Zuckerkandl and Pauling, 1962.

36 Zuckerkandl, 1963, p. 268. 
as formed through interactions among polypeptide chains, had to differentiated. One advantage of the primary structure was that in contrast to morphological traits that varied continuously, changes in amino acid sequences were discontinuous. The fact that proteins were clearly bounded also seemed to lessen the danger of a bias with regard to arbitrary choice of taxonomic characters, once the choice of which proteins to analyze in the first place had been made. However, phylogenies based on molecular difference might be distorted because of correlations such as the connection of change in one peptide to changes in others. On the other hand, correlation in the change of morphological traits may not necessitate correlated structural gene mutations (but only regulatory change). ${ }^{37}$ The molecular level was seen as less likely to misguide interpretations due to polygenic and pleiotropic effects than the organismal level. Furthermore, while the same phenotype may have several molecular make-ups, effects of convergence seemed to pose less of a problem in the investigation of proteins. In these respects, "[...] proteins are a 'cleaner' material for phyletic investigations than morphological characters." ${ }^{, 38}$

Overall, and here Zuckerkandl's own stance seems to come through, cause and effect relations were assumed to be clearer, the closer the analysis was to the basic structure of the genome. For those who held the notion of the gene as "clean" in the sense of "fundamental" and "bare of environmental distortion," protein sequencing could partially decrease the problems associated with phylogenetic reconstruction on the morphological level: "[...] the further away we get in the series of integrated biological levels from the gene level, the more disturbance is caused by environmental effects [...]." ${ }^{39}$ Evidently, the same characteristics of the molecular level of analysis were considered to be its disadvantage by some and its advantage by others. In the first case, the organism (and higher levels of integration) was prioritized as object of analysis because it represented the level of integration on which natural selection acted. In the second case, the gene/protein level was prioritized because it was least distorted by higher-level effects.

37 Dobzhansky and Mayr doubted the existence of these two kinds of genes. They thought that a structural gene may control the rate of activity of another gene, while regulatory or controlling genes would at the same time be structural (Zuckerkandl, 1963, p. 264).

38 Zuckerkandl, 1963, p. 260.

39 Zuckerkandl, 1963, p. 267. This point seems to have found support by G. A. Harrison (University of Liverpool; on this pros and cons discussion see also Dietrich, 1998, pp. 92-94). 
Although we have no transcripts of the discussions taking place at Burg Wartenstein on the subject of molecular anthropology, a paper on which Zuckerkandl and Pauling collaborated in 1963 may provide some further insights into the stance Zuckerkandl defended. In this, they thought about "molecules as documents of evolutionary history:" "We may ask the questions where in the now living systems the greatest amount of their past history has survived and how it can be extracted." ${ }^{40}$ The answer to the first question was, in the genes (or in DNA), in RNA, and in polypeptides. In this order of relevance, the molecules that carry the information of the genes or a transcript thereof were called primary, secondary and tertiary semantides. Zuckerkandl and Pauling defined the genes as the primary semantides in terms of "linear "sense carrying' units." ${ }^{41}$ In the semantides, "[...] there is more history in the making and more history preserved than at any other level of biological integration." 42

The history gleaned through comparisons between homologous polypeptides consisted in information about the approximate time of existence of a molecular ancestor, its probable amino-acid sequence, and the lines of descent along which given changes in sequence had occurred. That there were no "fossil" molecules, as had been bemoaned at Burg Wartenstein, was thus not necessarily seen as a disadvantage vis-à-vis paleoanthropology by Zuckerkandl. The techniques of paleogenetics allowed to reconstruct paleogenes. ${ }^{43}$ The hierarchy within the molecular system was explained on the basis of information drain. DNA was the most informative semantide because in the passage from primary to secondary, and from secondary to tertiary semantides, information was lost.

40 Zuckerkandl and Pauling, 1965b, p. 357 (the paper was first published in Problems of Evolutionary and Technical Biochemistry. 1964. Science Press, Academy of the Sciences of the USSR, pp. 54-62).

41 Zuckerkandl and Pauling, 1965b, p. 358. Genes are not clearly differentiated from DNA molecules in their definition of semantides. Rather, the primary semantides are first identified as the genes, and later more generally as DNA.

42 Zuckerkandl and Pauling, 1965b, p. 360.

43 In a paper with Linus Pauling, Zuckerkandl coined the term chemical paleogenetics for the restoration of information on paleogenes ("fossil" ancestral genes) through the reconstruction of ancestral amino acid sequences by comparisons of homologous polypeptides in contemporary organisms. This seems to be the first application of what later would be called the maximum parsimony method. The resulting paleogene, they envisioned, could eventually provide insights into the ancestral polypeptide's functions (Pauling and Zuckerkandl, 1963, p. 15). Today paleogenetics may not only refer to ancestral gene sequence reconstruction through comparisons of homologous genes in present organisms, but is also associated with the extraction and analysis of macromolecules from fossils. 
Isosemantic heterozygosity referred to differences in base sequences between alleles that did not result in differences in amino acid sequences, so that "the 'sense' of the 'word', in terms of amino acids, may remain the same." ${ }^{44}$ From gene to protein, information was also lost due to the fact that significant stretches of DNA were not expressed.

This was complicated by the possibility that some base substitutions, though cryptic at the level of the polypeptide chain, may affect the rate of polypeptide synthesis through differential transfer-RNA availability (secondary crypticity). Other substitutions would be cryptic also at the level of transfer-RNA (primary crypticity). On the basis of this observation, Zuckerkandl and Pauling reflected on what would later be conceptualized as neutral evolution at the molecular level:

If isosemantic substitutions recognized by transfer-RNA actually exerted an effect on rate of polypeptide synthesis, one would expect natural selection to act quite strongly on such substitutions. If natural selection did not act on the other postulated type of isosemantic substitutions, those of 'primary crypticity', not recognized by transfer RNA [sic], the occurrence of such substitutions would be random. ${ }^{45}$

However, Zuckerkandl and Pauling reasoned that natural selection was more likely to act also in the second case, due to some kind of as yet unknown phenotypic effect. ${ }^{46}$ At the same time, the degeneracy of the genetic code and the loss of information content associated with isosemantic substitution supported the notion of DNA as master molecule over polypeptides, even though the latter were involved in the regulation of synthesis rates of both kinds of molecules. Furthermore, it is of paramount importance that the possibility of primary crypticity opened up a totally new vista of a level of information more basic than that instantiated

44 Zuckerkandl and Pauling, 1965b, p. 361.

45 Zuckerkandl and Pauling, 1965b, p. 365.

46 This is therefore not a proto-neutral theory of molecular evolution. Gregory Morgan, 1998, discusses how the conception of the molecular clock by Zuckerkandl and Pauling did not go along with a notion of molecular evolution as mostly neutral, but that the idea of differential selection pressures causing differential resistances to change along the sequence of a protein was pivotal. They assumed that this resistance to change at changeable sites would be more or less constant and average out over time, resulting in a regular ticking of the clock. Due to the role ascribed to natural selection in protein evolution, Zuckerkandl did not argue for the independence of molecular from organismal evolution (on the question of "neutral mutations" see also below; on the development of Zuckerkandl's ideas concerning the importance of selection at the molecular level and the correlation of levels of evolution see also Zuckerkandl, 1987, and the interview between Gregory Morgan and Emile and Jane Zuckerkandl from 11 July 1996, at http://www.sfc.fr/material/hrst.mit.edu/groups/evolution/index.html). 
at any level of the phenotype. That meant beyond the realization of an organism in the sense of the totality of polypeptide chains that were actually synthesized and the structures that controlled this synthesis. It meant beyond even the potentiality of an organism in the sense of the polypeptides that could be synthesized at certain rates under certain conditions. There, a glimpse was caught of a time tunnel: "This part of its 'being', necessarily cryptic in terms of the phenotype, would at best be expressed only in relation to the evolution of the species. ${ }^{, 47}$ Differences in allelic sequences with no consequences on any higher level of the organism remained feasible, and Zuckerkandl and Pauling perceived their unique potential as "documents of evolutionary history." Nucleic acid substitutions of primary crypticity would represent an unmediated "record" of evolutionary change, completely undistorted by environmental effects.

Lily Kay has described the role of cybernetics and information theory in the transfer of information and communication discourse to living systems that took place in molecular biology in the time following WWII. This was complicated by the different information concepts involved. Whereas information theory worked with the 0 -1-information content concept, biologists thought of information in terms of meaning. ${ }^{48}$ The latter understanding of information is evidenced in Zuckerkandl's and Pauling's paper. They conceptualized the gene as master molecule in the sense of a linear sequence of nucleotides that was the most fundamental repository and communicator of phenotypic information (see italicized terms above). However, for Zuckerkandl and Pauling the genetic semantide might carry at least in its primary-cryptic nucleotides a kind of information that did not relate to the phenotype, but was of a purely evolutionary, and, as they called it, historical nature. As the ensuing discussion of the second Burg Wartenstein symposium will bring to light, the direct accessibility of this evolutionary "history" stored in the genes through new technologies marked a turn in the relationship between molecular and organismal anthropology. ${ }^{49}$

47 Zuckerkandl and Pauling, 1965b, p. 366.

48 Kay, 1994, 2000, Chaps. 3 and 4.

49 Independently from my writing of this article, Edna Suárez has composed a paper, in which "Molecules as Documents of Evolutionary History" figures centrally. She, too, is interested in its situatedness in the debates between molecular and organismal approaches to evolution, and perceives of the kind of language used by Zuckerkandl as of epistemic as well as of political value. Most importantly, she focuses on the epistemic and political dimensions of the metaphor of information, and the shift it undergoes in the paper by Zuckerkandl and Pauling towards a substitute for "history" (Suárez, 2007). However, Suárez does not link the claim for the prime epistemic value of the primary semantide to the notion of primary crypticity. 
Washburn later remembered that despite the disputes over classification between paleoanthropologists and evolutionary biologists, the main conflict at the 1962-Burg Wartenstein Symposium arose between those who stressed the importance of molecular anthropology (such as Goodman and Zuckerkandl) and the more traditional views of a Simpson and Mayr. ${ }^{50}$ Furthermore, Michael Dietrich has located the cause for the subsequent attacks on the molecular approach undertaken by Dobzhansky, Mayr, and Simpson in this very meeting. ${ }^{51}$ One may therefore suspect that the architects of the synthesis experienced a certain awakening at the conference to the potential threats the molecular approach could present to their project of an evolutionary synthesis in which anthropology was a centerpiece. As expressed in the quote from Dobzhansky that I use as a motto for this article, the differences between the potentially reductionist molecular and the more holist organismic approaches became particularly visible once they converged on questions related to man. Humankind occupied a special place in the synthesists' evolutionism, which as we will see was cause for attack by some molecular anthropologists. Because implicated in discussions about humankind's place in nature, the anthropological gene and genome, too, carried meaning beyond those of "other animals." 52

Again, it may well be that molecular and organismal biologists agreed about many conditions, but not about their conclusions. In retrospect, the synthesists' arguments for the irreducibility of evolution and phylogeny to the molecular level gain an ironic turn. Among these were: Natural selection takes place on the level of the phenotype; the effect of selection becomes more diffuse rather than clearer as one descends the hierarchy to the level of the gene; the further a character from the genes, the more likely it is to sample a number of genes, and

50 Washburn, 1983, p. 19

51 Dietrich, 1998, pp. 94-95.

52 On the human exception in the Evolutionary Synthesis see Sommer, forthcoming. I argue that Dobzhansky, Julian Huxley, Simpson, and to a lesser degree Mayr, introduced an epistemic break into their systems with the emergence of humankind. The special place of humans in the natural world allowed turning a not directed, only seemingly teleological kind of evolution into a potentially truly teleological one. Humans were the centerpiece of these cosmological systems, because in them the cosmos had become conscious of itself. Out of this consciousness about the evolutionary process grew the responsibility to become the managers of the future course of evolution. 
therefore to represent affinities of whole organisms. ${ }^{53}$ It was exactly the greater independence from selection that might disturb the record of phylogeny, the less entangled cause and effect relations, and the relative simplicity, discontinuity, and particularity of genetic characters that were used in favor of the molecular approach and that could be enlisted as arguments for the ideas of regularity and neutrality of evolution at the molecular level.

Furthermore, the above arguments may not only be seen as inadvertently helping prepare the way for the neutral theory of evolution at the molecular level. ${ }^{54}$ Simpson for one also imbued the notion of DNA as carrier of evolutionary history with authority, even while he attempted to turn the entire semantic field of the master molecule on its head. Mimicking the information discourse of molecular biology, he argued that the DNA was message as well as communicator, but not author of the message. It composed only mutations, and these were mostly deleterious. Rather, the message stored in the DNA and transferred in hierarchical feedbacks to higher levels was the result of natural selection working on phenotypic variation (based on genotypic variation) in a particular environment. Thus, natural selection orchestrated all integrative levels

${ }^{53}$ For reactions of the synthesists who were present at Burg Wartenstein in 1962 against "the glamour" of molecular biology as a scientific discipline and against its approach see for example Dobzhansky, 1964, 1966; Mayr, 1963a; Simpson, 1964, 1966a, 1966b, where he again made the argument that since we are obviously very different from a bacterium, our molecular similarity only suggests that molecules are the wrong level of comparison, and Simpson, 1964, 1966, 1967, 1969, Chaps. 1-2; on responses to the rise of molecular biology, in particular by biochemists, see Abir-Am, 1992.

${ }^{54}$ On the basis of the probable rate of evolution in terms of the entire genome, the Japanese geneticist Motoo Kimura, 1968, concluded that most nucleotide substitutions must be selectively (nearly) neutral. Otherwise, the mutation rate would be too high to be sustained by a mammalian population. The assumption of selectively neutral genetic change was associated with an increase in the importance of chance factors also for the evolution of non-founder, that is average-size, populations (genetic drift) (on the development of the neutral theory and its role as the first general theory of molecular evolution see Dietrich, 1994; see Schwartz and Maresca, 2006, for a critical discussion of the history of and current research in molecular systematics and the notion of molecular clocks). Edna Suárez and Ana Barahona, 1996, argue that Kimura was not solely influenced by the population geneticist discussion of the classical versus balanced hypotheses, but that the experimental results from molecular evolution (such as high rates of evolutionary change at the molecular level) were important for his first formulation of the neutral theory of molecular evolution. Furthermore, Kimura later incorporated empirically grounded assumptions into his theory such as were brought forward by Jack Lester King and Thomas H. Jukes, 1969, in their own version of nonDarwinian evolution at the molecular level (such as a molecular clock and the uncoupling of the molecular from the organismal level of evolution). 
between the phenotype as entire organism and the genotype. This argument for the importance of environments, populations, and organisms for heredity through natural selection seems to have rendered the notion of DNA as a message in the sense of evolutionary history less metaphorical: "Viewed in this way, it [natural selection] is the composer of the genetic message, and DNA, RNA, enzymes, and other molecules in the system are successively its messenger." ${ }^{55}$ In other words, according to this logic, natural selection inscribed DNA with organismic history.

Admittedly, from this line of reasoning also followed that the regularity and neutrality of change in proteins/genes was unlikely. Nonetheless, there might have been a more effective argument to discredit the notion of genes as carriers of evolutionary history, and thereby to argue for the greater importance of phenotypes for evolutionary reconstruction. Simpson might have pointed to the fact that if there was some substance to the idea of an internal constant-rate mutational process, it was indeed nothing but a measure of linear time. In fact, he did argue along these lines when defending organismic or evolutionary biology against molecular biology in general. He emphasized that in contrast to the biological sciences, the physical sciences were ahistorical endeavors, and their objects of study carried no history. Therefore, if molecular biology wanted to be anything but a contradiction in terms, if it wanted to make statements about the living world rather than the chemical world, it could not have repeatability and predictability as central epistemic virtues. Historical sciences had to deal with contingency and the uniqueness of objects and events. ${ }^{56}$ Let me try

55 Simpson, 1964, p. 1538. Note that for Washburn, it was exactly this argument for the centrality of behavior as ultimately directing the course of (genotypic and phenotypic) evolution through the feedback mechanism of natural selection (i.e. adaptation) that made it possible to embrace the molecular anthropological approaches and results from the start, some of which he had stimulated (Washburn, 1967). If "the human gene pool is the result of the behaviours of past times" (p. 25), the analysis of genes might well provide information far beyond phylogenies and divergence times, and they might well be seen as at the basis of a more integrative approach to human evolution. The recent divergence of African apes and humans as established through molecular anthropology were also less difficult for Washburn to integrate, since he had never accepted a phylogeny with very old independent lineages, but as early as the 1930s believed the two had shared a relatively recent brachiating stage.

56 Simpson, 1964, 1966, 1967, 1969, pp. 9-10, for an elaborated treatment of the topic see Simpson, 1964 (1963) (on Simpson's emphasis on paleontology as a historical science in his self-assertion vis-à-vis molecular biology see Aronson, 2002); Mayr attempted a similar differentiation with his distinction between functional sciences that are concerned with proximate causes, such as functional anatomy and molecular biology, and sciences concerned with ultimate causes, or questions of how something came about historically, such as evolutionary biology (see for example Mayr, 1961). 
to apply this argument to anthropology: If the molecular approach could measure units of time after lineage separation, it was therefore a (nearly) metrical device, the function of which stood in opposition to the notion of the gene as a repository of historical events on the population level. Indeed, the statistical nature of mutations was often analogized to the Poisson distribution of radioactive decay. As it was, however, the molecular anthropologists would have the cake and eat it. They would postulate the independence of molecular from phenotypic evolution on the basis of the neutral theory of molecular evolution and claim that DNA was the most important object in historical reconstruction. ${ }^{57}$

It is unclear in how far such discussions about the contribution or challenge from molecular anthropology to biological anthropology had been anticipated for the 1962-Burg Wartenstein symposium. The symposium's agenda seems rather to have been the rewriting of human evolution from the theoretical underpinnings of the synthetic theory of evolution, a notion corroborated by the closing articles by Mayr and Dobzhansky. Like Simpson at the beginning of the volume, Mayr in his contribution emphasized the need to reform fossil hominid classification on the basis of population thinking. Also like Simpson, he accepted the data from molecular anthropology in so far that the African apes were confirmed to be closer to humans than the orangutan or gibbon. At the same time, Mayr emphasized the large morphological differences between humans and apes. Once again, the adaptive niche of Homo was considered causal for the difference in grade. It seemed that the hominid niche had necessitated a drastic reconstruction of morphology associated with bipedalism, tool making, and language, but not a complete revamping of the biochemical system. ${ }^{58}$ As we will see in the following, this differentiation between the two kinds of evolution would eventually be accepted by molecular anthropologists who used it to turn the argumentation for the epistemic priority of organisms in phylogenetic reconstruction on its head.

Also Dobzhansky's main target was the residue of outdated typological approaches in both traditional morphology and in the newer molecular anthropology. But Dobzhansky's text shows that besides these approaches to anthropological problems, there was yet another way of thinking that needed to be fended off. The population geneticist Dobzhansky saw his field threatened by ideas such as those of the

\footnotetext{
57 Simpson remained an opponent of molecular anthropology and its theory of a molecular clock (see for example Simpson, 1981; see also Dobzhansky and Boesiger, 1983, pp. 50-51).

${ }^{58}$ In this Mayr, 1963b, also drew on Schultz, 1963 b.
} 
anthropologist Frank Livingstone (b. 1928). Cline theory represented the other extreme from the typologists with respect to the question of discrete units at the sub/species level. ${ }^{59}$ According to Dobzhansky, organisms in one vertical line of descent formed a continuum. This meant that the boundaries between groups of organisms that temporally succeeded each other were arbitrarily produced by superimposing the discontinuity of the fossil record on natural continuity. To the contrary, between contemporary organisms there existed real discontinuity. Contemporary races and species were natural entities, even if populational rather than typological:

Races, breeds, or subspecies are, on the contrary [to species], genetically open systems [...] Gene diffusion between races often finds visible expression in geographic character gradients, or clines. Such gradients may make it difficult or impossible to draw clear lines of demarcation between the races, especially when the gradients in different characters are uncorrelated. This difficulty has been used by some authors as a basis to argue that man has no races, or even that races in general do not exist. This is about as logical as it would be to argue that youth is not different from old age because the gradient between the two is almost completely smooth. ${ }^{60}$

This is significant in our context, because while Dobzhansky emphasized development in grades over development in clades (that is gradual progress without much speciation), he provided the basis on which molecular anthropology would build in two important respects: Human races could be meaningfully differentiated in a populational approach, and their differences represented a natural order. Furthermore, although Dobzhansky, who had made an effort to familiarize himself with paleoanthropology, did not grant the molecular level epistemic precedence over morphology, he was working with a conception of living systems as integrated hierarchical levels, at the basis of which was the gene: "Biology is the study of life. The lowest, or most elementary, or most fundamental living unit is a gene. A gene is a bit of matter, as far as known always containing, or composed of deoxyribonucleic or ribonucleic acid. This remarkable substance can engender, in proper environments, synthesis of copies of itself." 61 However, he immediately

59 See Livingstone, 1962, which contains a reaction by Dobzhansky.

${ }^{60}$ Dobzhansky, 1963, p. 351; on the post-WWII development of population genetics and its usage of the concept of race see also Gannett, September 2001; Reardon, 2005, particularly Chap. 2.

${ }^{61}$ Dobzhansky, 1963, p. 347. 
qualified that since scientists simply tended to regard as most basic the object they themselves studied, one might just as well prioritize the organism as the most fundamental unit of evolutionary analysis. As we will see in the next section, this turned out to be more than a "just as well" discussion.

\section{Genes as Documents of Evolutionary History and the Burg Wartenstein Symposium of 1975}

On the days from 25 July to 1 August 1975, another symposium was held at Burg Wartenstein that also defined the phyletic position of Homo sapiens in the order of the primates and the trends at work in human evolution as its concern. However, the main issue was molecular anthropology, and the conference title took up Zuckerkandl's neologism of the previous conference: "Progress in Molecular Anthropology." The title of the resulting volume combined the two interests to Molecular Anthropology: Genes and Proteins in the Evolutionary Ascent of the Primates (1976). ${ }^{62}$ Rather than a theorist of the new synthetic anthropology, it was now Goodman and the human geneticist Richard E. Tashian who edited the volume, assisted by Jeanne H. Tashian (both of the University of Michigan Medical School). The Wenner-Gren sponsored meeting brought together experts from protein and nucleotide chemistry, genetics, statistics, paleontology, and physical anthropology, but the balance had changed. In fact, the 1976 volume included only two papers from classical paleoanthropology. The molecular approaches comprised primary amino-acid sequencing of hemoglobins, myoglobins, carbonic anhydrases, and immunoglobulins, as well as immunological analyses of serum proteins and DNA hybridization. Finally, different mathematical models were discussed as techniques for statistical interpretation of the comparative molecular data.

At its extremes, the gap had widened, even though the non-molecular and molecular approaches were not distributed strictly along the lines of disciplinary training of the participants. Physical anthropologists in the main maintained the very early divergence of the hominid and pongid lines on the basis of fossils such as Ramapithecus. ${ }^{63}$ On the other hand, some of those working in molecular anthropology had gained trust in

\footnotetext{
62 Goodman, et al., 1976.

${ }^{63}$ Simons, 1976; Walker, 1976.
} 
the molecules, and began to interpret little molecular difference as short separate evolutionary lines. ${ }^{64}$ Indeed, in a recapitulation of the debates held and the findings presented at the conference, Goodman and the Tashians reported that "[t]he notion of the intrinsic superiority of molecular data over data from the fossil record was introduced. Analysis of the fossil record has apparently been more subjective than analysis of molecular data, which lends itself better to techniques of rigorous mathematical logic." 65

This verdict might astonish in view of the lack of agreement among those working on molecular evolution and phylogeny. The greatest controversy concerned the feasibility and nature of the molecular clock(s). The problem persisted that homologous proteins did not seem to evolve at the same rate in different phyletic lines, nor different proteins within the same line. Could one assume a regular clock at all, and if so, was it to be found in particular proteins or in the entire genome? How should time be measured-linearly, or in replication cycles or generation times? What was the mode of mutation fixation and which functional effects, if any, did mutations have? Should one focus on presumably selectively neutral molecular traits only? Were the main differences between anthropoids and humans located in the regulatory apparatus of the genome rather than in structural genes/proteins, and what would that mean for the concept of a molecular clock? This possibility based on the insight that due to mutations in regulatory gene regions, relatively little variation in proteins might correspond to large morphological differences. Related questions were: Did the computer algorithm of maximum parsimony, which could not take parallel and back mutations into account, work, or was one of the several alternative methods of molecular tree construction preferable? Were sequence comparisons generally misleading because the specificity

${ }^{64}$ On the widening of the gap between molecular evolution and non-molecular evolutionary biology, as represented by Dobzhansky, Mayr, and Simpson, and the gaining of ground by the first, see Dietrich, 1998, pp. 95-109; see for example also Uzzell and Pilbeam, 1971, who discussed the relative merits of morphological and molecular approaches to primate phylogeny and found the more recent divergence dates arrived at through the latter less robust. However, Joel Hagen, 1999, in his discussion of the conflict between naturalists and molecular biologists concerning molecular evolution, warns of simplifying the positions of what was a multifaceted contest (see particularly pp. 328-329). As we have already seen in the previous section, and as will become more obvious in the course of this one, the more particular issues of human evolution created similarly diverse debates, with approaches from classical paleoanthropology, organismic population genetics, and biochemistry and molecular biology forming neither consentaneous groups nor groups strictly defined according to their members' training.

${ }^{65}$ Goodman, et al., 1976, p. 493. 
of species resided in the inter-hierarchical relationships of their organ systems? ${ }^{66}$

The case was complex enough for the primates, but some followed Livingstone in warning of the particularly difficult situation for human population studies, due to the influences of parallel evolution, culture, and interbreeding. The biochemical methods for studying primate and intra-human phylogenies were essentially the same, but in the latter case the branches of a cladogram could not be read as representing reproductively isolated groups. As the anthropologist Gabriel Lasker (19122002; Wayne State University School of Medicine) pointed out, such a cladogram could at best be approximate, since "the branches in a phylogenetic tree" that represented human variants were in reality interconnected. ${ }^{67}$

Despite these uncertainties, there were those among the molecular anthropologists who left no doubt about the superiority of the molecular method vis-à-vis morphology, such as the American bio-anthropologist Vincent Sarich (b. 1934). With the New Zealand-born biochemist Allan Wilson (1934-91), Sarich had been one of the pioneers in the application of immunological analysis to primates in the $1960 \mathrm{~s}^{68}$ They developed the immunological clock hypothesis on the premise of a mathematical relationship between "the immunological distance" (degree of cross-reaction) and the time of divergence of any two species. This presupposed that amino acid sequence changes in serum albumin had occurred approximately regularly over time in the lineages compared. Sarich and Wilson used the 30-million-years assumption for the Old World monkeys-apes split from paleontology to set the molecular clock. Their results indicated that modern humans and African apes had shared a common ancestor as recently as five million years ago. This played havoc with many phylogenies based on fossil evidence (Figure 4).

The revolutionary work had been carried out at the University of California, Berkeley, where the prototype of the molecular evolution laboratory had been set up in 1965 under Wilson, and from where a diaspora of researchers would spread to laboratories around the world. Throughout the course of his career, Wilson trained more than 200 graduate students and post-docs. Indeed, a critical number of scientists

\footnotetext{
66 See for example Gatlin, 1976; Holmquist, 1976; Moore, 1976; Vogel, et al., 1976.

${ }^{67}$ Lasker, 1976.

${ }^{68}$ Sarich and Wilson, 1967. Sarich and Wilson also applied the immunological approach to other groups, such as to pinniped phylogeny (see for example Sarich, 1969).
} 


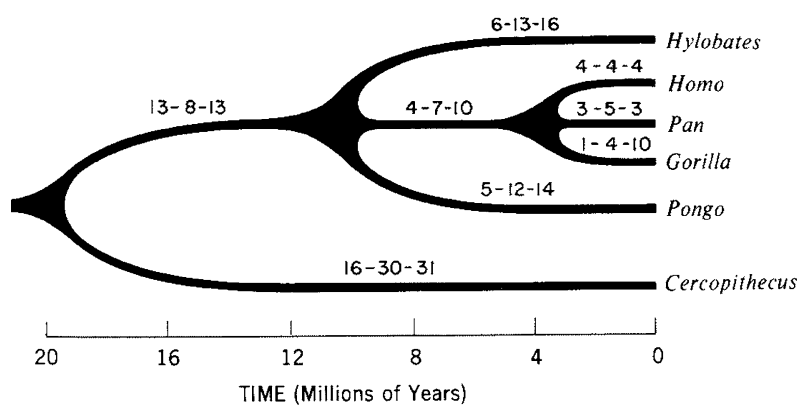

Figure 4. Albumin (units of change), transferrin (units of change) and DNA (units in dissociation time of hybrids) phylogeny of the Hominoidea based on the molecular clock; from Sarich, Vincent M., and Cronin, John E. 1976. "Molecular Systematics of the Primates." In Molecular Anthropology. Genes and Proteins in the Evolutionary Ascent of the Primates, edited by Goodman, Morris, Tashian, Richard E. and Tashian, Jeanne H. New York: Plenum, p. 151, Figure 7. (c) 1976 Plenum Press, New York, reproduced with kind permission of Springer Science and Business Media.

who worked in empirical molecular evolution in the 1970s and 1980s have a pedigree that can be traced back to the Wilson laboratory, and "the family tree" that sprouts from there reaches into laboratories around the world (Figure 5). ${ }^{69}$ Sarich had been recruited by Washburn as $\mathrm{PhD}$ student for the anthropology department as a consequence of the 1962-Burg Wartenstein conference, when Washburn wanted a specialist in what he perceived as the strong methods of molecular anthropology for the implementation of his new physical anthropology. Sarich should be trained by and work with Wilson in the newly set-up laboratory. ${ }^{70}$ Washburn heralded the new technologies as finally providing some scientific base to claims about human evolution. At a meeting of the Western Center of the American Academy of Arts and Sciences, he would ridicule comparative anatomy as a kind of pseudoscience that had given rise to just-stories about human evolution:

Many of the problems of traditional evolutionary thinking arise from the fact that comparative anatomy is basically a primitive, nineteenth-century science that has not been reorganized, and in my opinion cannot be reorganized, without first accepting molecular

69 For the early history of this laboratory see Creager, 1996.

${ }^{70}$ Sarich and Miele, 2004, pp. 111-112; Washburn, 1983, p. 21. 


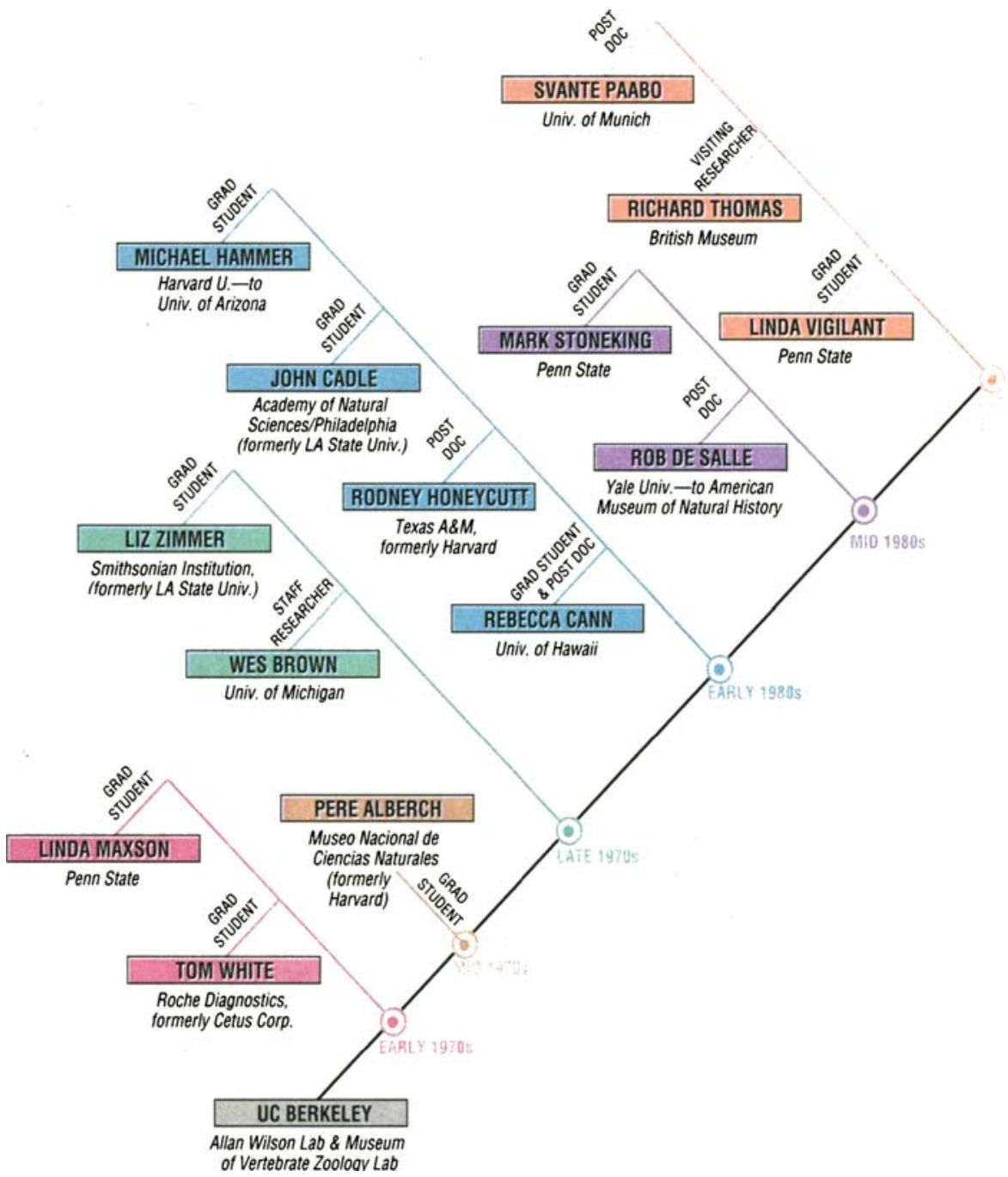

Figure 5. 'Family tree' of the Allan Wilson laboratory at the University of California, Berkeley, for its 25th anniversary; from Gibbons, Ann. 22 February 1991. "Systematics Goes Molecular." Science, New Series 251 (4996):872-874, on p. 872. Reprinted with permission from AAAS.

biology and working with a set of bases and problems very different from those the traditional comparative anatomist worked with. ${ }^{71}$

Condemning the earlier notion of evolution as guided by progress, Washburn drew a progressive picture of the evolution of the human origins

71 Washburn, 1982, p. 39. 
sciences from fossil-free accounts, to nonsense stories, to the synthesis and the age of molecular biology and dating techniques (accompanied by some stagnations and atavisms as indicated in the quote above).

Sarich shared his former PhD supervisor's confidence in the application of physical and biochemical methods to questions of anthropology. In the volume Background for Man (1971) that he co-edited with Berkeley primatologist Phyllis Dolhinow (b. 1933), he repeated the common argument that the anthropological sciences were peculiar because the researchers were also the objects of study: Anthropology is of such immediate relevance to our view of self that anthropological knowledge is especially prone to bias. Sarich claimed that it was only with the advent of the objective technologies of chemical and radioactive dating, and later the biochemical approach to reconstructing the evolutionary relationships of the living primates, that the deeply ingrained belief in the human exception began to weaken. Through these technologies the acceptance of the phylogenetic closeness of human to non-human primates gained ground. Sarich accused traditional comparative anatomy of the inability to develop methods robust enough to lead to agreement on the question of primate phylogeny and times of divergence, even on the basis of the same paleontological data. However, he saw the feat now achieved in independent molecular studies, and Sarich therefore felt justified in demanding priority for their results: "one no longer has the option of considering a fossil specimen older than about eight million years a hominid no matter what it looks like." 72

Clearly, here was a new tenor. It professed neither the conciliatory tactics of a Goodman, who continued to subordinate his results from immunological studies to the line-split dates from paleoanthropology, ${ }^{73}$ nor the careful consideration of evolutionary complexity evidenced by Zuckerkandl. ${ }^{74}$ In their paper for the 1976-Burg Wartenstein volume, Sarich and his Berkeley colleague John Cronin attacked "[...] the distortion of anthropoid taxonomy caused by giving man his 'proper' rank." 75 The distortion they perceived in traditional phylogenies consisted in separate taxa for the African-apes group and humans as well as in their long independent lines of descent. While the data that came out of the molecular laboratories were "[...] direct, quantitative, and objective," arguments for a special treatment of humans within the

72 Sarich, 1971, p. 76.

73 Dene, et al., 1976; Goodman, 1976.

74 Zuckerkandl, 1976.

75 Sarich and Cronin, 1976, p. 166; a point on which Goodman, 1976, p. 340, partly agreed. 
primate taxonomy, or discussions about the meaning of molecular differences "[...] involve a good deal of advocacy and emotionalism."

By the time of the 1975 conference, Sarich and Cronin could look back on at least fifteen years of molecular anthropological techniques, and they knew what they expected of the future:

The documentation of the validity of this claim has only just begun, of course, and convincing the interested scientific community of it remains the most important task of the molecular systematist. As this is accomplished, we may expect a burgeoning interest in, and use of, immunological, DNA hybridization, and electrophoretic techniques to solve problems of evolutionary relationship. ${ }^{77}$

"This claim" reverberates with the assertion made earlier in their chapter in the conference volume: "We believe that the potential of proteins and nucleic acids to provide such cladistic and temporal information is inherently greater than that of more traditional sources of comparative data." 78 The longer passage is also notable because the technique of sequencing is omitted. Indeed, Sarich and Cronin felt the need to defend their particular method within molecular anthropology. There were now four basic techniques: amino/ribonucleic/deoxyribonucleic acid sequencing, electrophoresis, nucleic acid hybridization, and immunology. Sarich and Cronin were upset about the fact that sequencing had achieved the status of a holy grail, while the three indirect approaches were being comparably neglected. Even though sequencing was still too expensive and time consuming, and seemed unlikely to be more easily available in the near future. We have met with the prioritization of direct sequencing already at the precursor conference. In the 1976 volume, the section of papers on amino acid sequence data was allocated the largest amount of space. But the protest from Sarich bears a certain irony. Sarich's claim for the truth of the molecules was so strong that he saw fossils as epistemologically subordinate, partly based on the more direct approach of molecular anthropology. Now he had to argue against the lure of "direct evidence.",79

76 Sarich and Cronin, 1976, p. 164.

77 Sarich and Cronin, 1976, p. 167.

78 Sarich and Cronin, 1976, p. 142.

79 In the 1980s, Sarich would pick up a fight against researchers who had used the DNA-hybridization technique to arrive at a hominoid phylogeny that differed from the one he promoted, i.e. that showed a tighter clustering of chimpanzees and humans, rather than a trichotomy containing both African apes and humans (see Lewin, 1988a, $1988 \mathrm{~b}$, on the personal quality of the fights, and the politics of science it revealed). 
Sarich and Cronin also positioned themselves against Goodman's notion that mutation rates were slowing down in higher grades. They conceded that not all proteins showed the same rate of mutation (or indeed changed regularly), but argued for the testability of mutation rates (clocks). ${ }^{80}$ In cases for which regular mutation rates had been shown, one should work with these regular rates regardless of their cause. One should not look for explanations such as Darwinian selection or random and neutral mutation. Similarly, mutations in regulatory genes that were likely to have been involved in sudden major changes linked to adaptation/speciation should be treated separately. ${ }^{81}$ However, in the meantime, the molecular clock had found a theoretical underpinning in the neutral molecular evolution hypothesis. Indeed, by then Sarich and Wilson argued for the particularity of molecular evolution vis-à-vis phenotypical evolution. They were seen as determined by different sets of parameters and to proceed at different rates. Evolutionary change in structural genes was describable by the concept of an evolutionary clock and the neutral theory of mutation, complemented by functional-constraints and dispensability factors. Phenotypic evolution, on the other hand, was related to other phenomena on the molecular level such as mutations in regulatory sequences and chromosomal morphology. ${ }^{82}$

Within such a line of reasoning, Zuckerkandl's and Pauling's tentative argument for a cryptic kind of information in the genes that was solely related to evolutionary history could gain full force. Furthermore, by 1975 , the prospects of molecular anthropology had taken a great leap forward in the practical fulfillment of Zuckerkandl's dream of extracting history from the primary semantides. In the conference volume, the geneticist K. W. Jones (Edinburgh University) presented the results from satellite DNA cross-hybridization experiments on anthropoid apes and humans. He introduced a study on the relative distribution of related satellite DNA in humans and the chimpanzee on the basis of restriction enzyme fragments through hybridization. Jones approached the supposedly most basic level of information on the premise that "[t]he DNA of a species documents its evolutionary history." ${ }^{83}$ Equally

\footnotetext{
${ }^{80}$ Sarich had developed what came to be called the relative rate test, which consisted in testing the rates of amino acid change in the taxa under consideration against out-groups. For example, human, baboon, spider monkey, and tarsier albumins were similarly different from those of a loris, a lemur, a dog, or a bear. This indicated that there had been no slow-down in the change rate in the human line.

${ }^{81}$ Sarich and Cronin, 1976.

82 Wilson, et al., 1977; see also Dietrich, 1998, pp. 108-109.

83 Jones, 1976, p. 357.
} 
importantly, satellite-DNA, which was presumed to be non-coding, consisted in very short, highly repetitive, and fast evolving nucleotide sequences. Jones's research therefore brought to the fore the persistent interest in human genetic variability. A relatively young kind of human satellite DNA raised hopes of approaching more recent aspects of hominid evolution through its study in "existing racial groups" another of Sarich's seminal visions. ${ }^{84}$

At the second Burg Wartenstein symposium, the prospects of molecular anthropology continued to seem promising, and the molecular data converged with regard to the primate branching pattern. Gorilla, Pan, and Homo were confirmed as more closely related to each other than any of them to Pongo. And several molecular analyses suggested that Pan and Homo were even more closely related. The molecular clock hypothesis had gained momentum through accumulating data, theoretical developments, and methods for molecular tree building. However, it was also considerably complicated and repeatedly doubted. It was calculated to be only approximate. This could be explained for example by gene duplication that happened prior to the divergence of two species, with the result that one compared paralogous instead of homologous genes. Furthermore, random genetic drift in small populations could actually accelerate mutation rates. The mutation rate of a gene might also be really accelerated following functional changes in proteins. Once the new function would have been optimized, a slowdown in mutation rate might ensue. Apparent deceleration, on the other hand, could be due to independent mutations that led to the fixation of the same nucleic acid at a given site. ${ }^{85}$

For some, including Zuckerkandl, a less than perfect clock was still a clock. This meant that the differences in modes between molecular and morphological evolution were real and needed to be explained. As we have seen, morphological evolution was correlated with mutations in controller sections. Correspondingly, fixation of mutations in structural genes was seen as less functionally constricted, without negating interrelations of the two genetic ways of organismal change. ${ }^{86}$ Therefore, Zuckerkandl's belief expressed in the discussions of 1962 that there were different kinds of genes had become substantiated. This involved a more

${ }^{84}$ In Jones, 1976, p. 364. On the stabilization of satellite DNA as a phenomenon in the course of DNA hybridization research see Suárez, 2001. In this process, hybridization, or reassociation, itself returned from being a technological object to being an epistemic object.

${ }^{85}$ See for example Dene, et al., 1976; Fitch and Langley, 1976; Goodman, 1976; Matsuda, 1976; Romero-Herrera et al., 1976; Tashian et al., 1976.

${ }^{86}$ Zuckerkandl, 1976, pp. 435-438. 
complex notion of genes and genomes. At the same time, within coding regions it brought greater independence of structural anthropological genes and genome sections from phenotypic evolution and its mechanism of natural selection. Paradoxically, this amounted to the possibility of a stochastic clock at the molecular level and simultaneously of genetic areas of crypticity that had been claimed as the most authentic documents of evolutionary history.

For others the challenges to the clock concept as presented in particular by the observed slowdown in higher grades of the primates that had been an issue ten years earlier were more serious, and the interpretation of molecular analyses therefore more dependent on data from the fossil record:

To have a truly effective genealogical description and classification of the primates, the molecular findings need to be integrated with fossil evidence. The latter can provide a time scale, which in turn can serve as a yardstick for designating the hierarchical level of the groups to be described in the classification. ${ }^{87}$

To arrive at "a natural or truly evolutionary system of classification," it was mandatory that primate paleontologists joined with molecular anthropologists. As is the concern of the next section, both wishes materialized: Sarich's for a molecular approach to intra-human evolutionary history and diversity, and Goodman's for greater synergy between the molecular and the organismic anthropology. Finally, at the 1975-Burg Wartenstein symposium, Zuckerkandl's hopes for the future of molecular anthropology included a follow-up conference to be held in ten years time, which, too, in a certain way turned out to be prophetic. ${ }^{88}$

\section{Mitochondrial DNA and the Molecular Revolution in Anthropology}

In 1984 plans were made for a conference on "origins and dispersal of modern humans" that finally took place in 1987 (22-26 March), even if this time, Burg Wartenstein was not the host. ${ }^{89}$ This conference, located

87 Goodman, 1976, p. 340.

88 Zuckerkandl, 1976, p. 443.

89 Three years after the 1975-Burg Wartenstein conference, the chairman of the board of the Wenner-Gren Foundation for Anthropological Research announced the cessation of the annual conference program at Burg Wartenstein in the form it had existed since 1958. The castle was sold in 1980, due to inflation, the declining value of the dollar, the rising Austrian economy, and the situation of the Foundation's endowment (Wadsworth, 1978). 
in Cambridge and financed by British institutions, stood under the aegis of the archeologist Paul Mellars of the University of Cambridge and the paleoanthropologist Chris Stringer (b. 1947) of the British Museum of Natural History in London. As Zuckerkandl had envisioned, the international conference brought together specialists from human evolution, archeology, and molecular genetics to discuss the revolutionary developments in molecular biology and their meaning when applied to human evolution. The papers on the biological subjects were collected in the volume The Human Revolution (1989). ${ }^{90}$ Indeed, the 1980s brought a revolution in more than one respect. In the late 1970s, restriction enzymes of high specificity had become available that allowed the comparison of individual human DNA on the sequence level. These enzymes cut DNA at precise locations defined by longer sequences, so that the individual differences in the resulting fragments were due to mutations in these restriction sequences. Such variations were therefore called restriction fragment length polymorphisms (RFLPs).

Thus, as foreshadowed at the 1975-Burg Wartenstein conference, the turn towards the master molecule coincided with the turn to intrahuman genetic variation. ${ }^{91}$ The theoretical basis for this interest had been laid long before. As we have seen, the synthesists regarded human "races" as meaningful biological entities and therefore as epistemological objects of population genetics. However, although the interest in modern human evolution and diversity had never subsided, the tools to study these directly on the level of DNA had only just begun to appear on the horizon..$^{92}$ As we have seen, one such beam of light had been satellite DNA. What were needed were regions of DNA that showed high enough mutation rates to function as "carriers of the very recent history of human diversification." This dream came true with a single, circular strand of cytoplasmatic DNA. The very year of the Cambridge conference set a landmark in molecular anthropology thanks to the fabulous object, mitochondrial DNA (mtDNA). At least one of the participants, the geneticist Rebecca Cann, attributed greater authority to its analysis than either to traditional morphological studies or molecular studies of nuclear DNA and proteins. Generally speaking,

90 Mellars and Stringer, 1989.

91 This is not to suggest that the techniques of DNA sequencing were not also applied to the puzzle of hominoid phylogeny, where they actually led to the breakthrough of the view of a recent Homo-Pan split, with a slightly earlier gorilla divergence, as advocated by Goodman in the 1960s (see Gibbons, 1990).

${ }_{92}$ Research that assessed genetic differences between human groups indirectly reaches back to the blood group surveys during WWI, and experienced a first high in the 1960s (Cavalli-Sforza and Edwards, 1967). 
genes of living humans were better suited for the reconstruction of phylogenies than fossils:

There is no direct evidence that any individual in the fossil record with a particular phenotype and genotype left genes in modern descendents, yet geneticists operate with $100 \%$ certainty that genes in modern populations have a history that can be examined and will trace back in absolute time to real ancestors. This asymmetry demonstrates the inherent power of genetics to deal with evolutionary issues (27)..$^{93}$

More particularly, mtDNA was the perfect epistemological object for analyzing modern human evolutionary history and diversity due to three main virtues: It was relatively simple to analyze; it evolved rapidly, due to the lack of an efficient repair system; and it was inherited strictly maternally and therefore was free of the complexities caused by recombination. The fact that none of these virtues has gone unchallenged need not concern us further. However, Lasker's warnings in his opening paper to the 1976-Burg Wartenstein volume about the pitfalls of molecular phylogenetic studies of human diversity were now more urgent then ever, when "[...] in the last few years [...] this topic [has] really taken off to become (currently) one of the most central and controversial in the whole field of palaeoanthropology." 94

As the controversial primate phylogeny on the basis of the immunological clock twenty years earlier, the mtDNA news came out of the Berkeley laboratory (compare Figure 5). MtDNA of approximately 150 people from what were called African, Asian, aboriginal Australian, Caucasian, and New Guinean populations was sequenced (RFLP maps). The results of the mtDNA study were published in an article in Nature that contained a "human family tree" based on mtDNA types. ${ }^{95}$ This diagram was reproduced in the contribution with which Mark Stoneking and Cann opened the section on biological change in The Human Revolution volume. ${ }^{96}$ Of course, this could only be read as human family tree if the people, and the geographical groups they were assigned to, were identified with "their mitochondrial DNA." In fact, it

\footnotetext{
93 Cann, 1988, p. 127.

94 Mellars and Stringer, 1989, p. 1.

95 Cann, et al., 1987. There were several important precursor papers on human mtDNA analysis. The method was pioneered by Wes Brown, who was brought to Berkeley by Wilson to continue on his mtDNA technology and results (see for example Brown, et al., 1979; and Brown, 1980).

${ }^{96}$ Stoneking and Cann, 1989.
} 
was a computer-built diagram of sequence differences in mtDNA molecules, based on maximum parsimony and midpoint rooting (Figure 6).

Beyond phylogeny, the results suggested a scenario of human evolution. They supported the interpretation that all human mtDNA referred back to a female who had lived in Africa some 200,000 years ago. The African Eve Theory or Recent African Evolution model that emerged from these data was a prehistory of human origin, migration, separation, and struggle reminiscent of the Biblical narrative (and innumerable other tales of human quest). Modern humans had originated in Africa (that is modern Homo sapiens evolved from archaic in Africa), from where they began to migrate some 100,000 to 140,000 years ago to eventually spread across the globe. In the process, the modern human newcomers completely replaced archaic Homo sapiens (including Neanderthal) in Asia and Europe. ${ }^{97}$ Both, the more specific results that modern humans arose in Africa and subsequently populated Eurasia and America, and the general conclusion that tools for DNA analysis were the key to human history, were confirmed by further studies presented at the conference. An analysis of the geographic distribution of human globulin gene cluster polymorphisms, research on paternal ancestry of modern humans on the basis of a Y chromosome sequence, and a paper on molecular genetics and patterns of human evolution told similar stories. ${ }^{98}$

It is this heroic narrative of human incarnation and conquest of the globe that constitutes The Human Revolution of the conference volume. However, it can be understood as referring to either the model of rapid emergence of modern humans in the course of evolution, or to the revolution brought about in the sciences of human origins by "[...] the fast-developing field of what might be termed 'palaeogenetics' - historical reconstruction from present-day genetic data." "99 It indeed seems that the practices, objects, rhetoric, and the content of the science were inseparably intertwined. After all, it was in the course of the development of molecular approaches to anthropological questions that the human gene and genome were inscribed with the most reliable traces of human evolutionary history in the first place. Eventually, the "technological revolution" enabled molecular anthropologists to set the revolutionary story of human becoming free.

97 The association of the African Eve theory with the female line and with an African origin immediately triggered sexist and racist reactions that purportedly took issue with the science of the research (Cann, 1997). The storyline has been retold many times since, and quite often in explicitly Biblical terms (see for example below).

98 Lucotte, 1989; Rouhani, 1989; Wainscoat et al., 1989.

99 Mellars and Stringer, 1989, p. 1. 


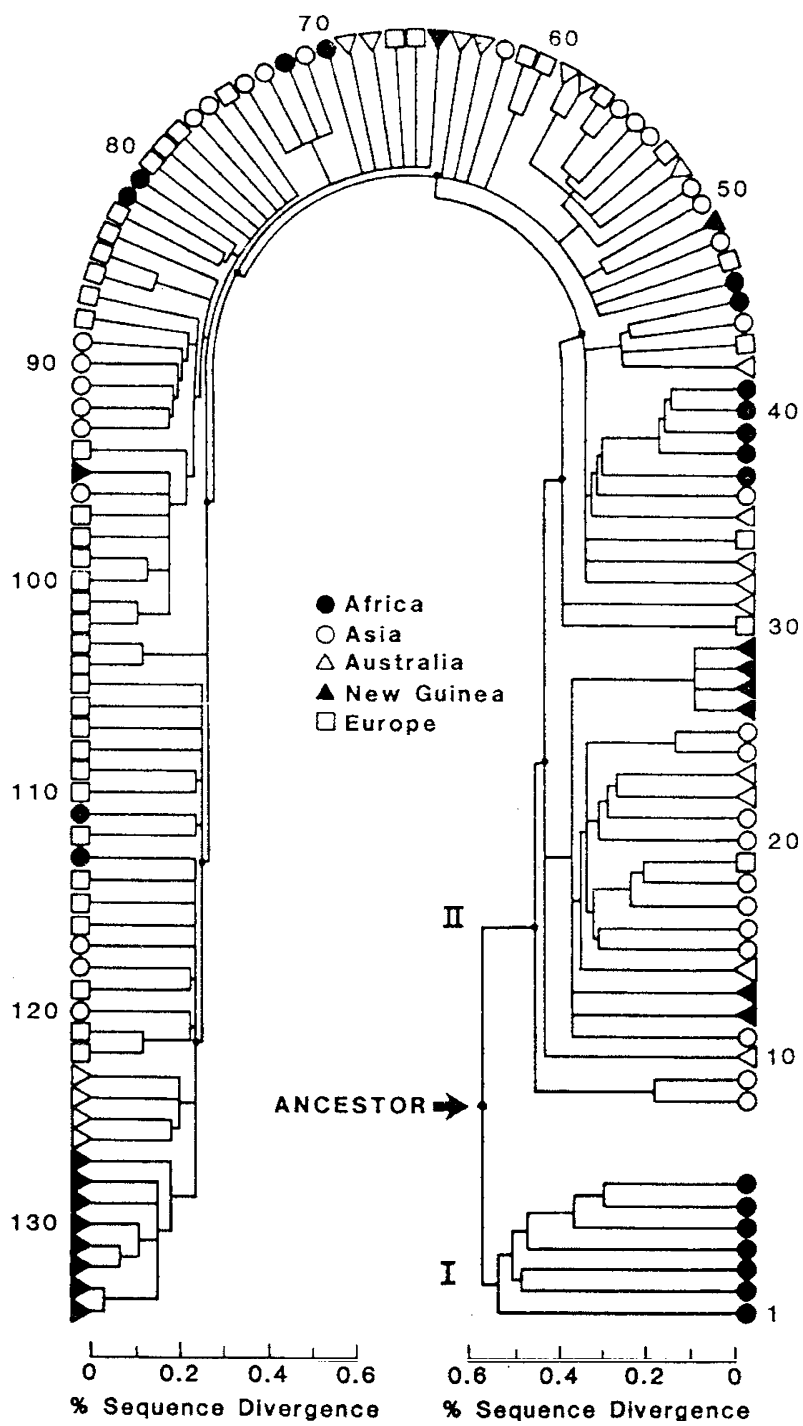

Figure 6. 'Family tree' of 134 mtDNA types derived from 148 people occupying five different geographical regions; the tree was constructed by a computer program on the basis of restriction maps, the parsimony method (minimization of total number of mutations), and midpoint rooting (hypothetical ancestral sequence located in the middle of the greatest distance between any two mtDNA types); it suggests that the greatest mtDNA diversity exists among sub-Saharan Africans, an African origin of modern humans, and a relatively recent divergence of modern human 'racial' groups; from Stoneking, Mark and Rebecca Cann (1989). "African Origin of Human Mitochondrial DNA." In The Human Revolution. Behavioural and Biological Perspectives on the Origins of Modern Humans, edited by Mellars, Paul and Stringer, Chris. Edinburgh: Edinburgh University Press, p. 18, Figure 2.1. Reprinted with permission from Edinburgh University Press, http://www.eup.ed.ac.uk. 
The revolution in anthropology and the human revolution were part of new scientific constellations. In contrast to the Burg Wartenstein symposiums, where the molecular analyses tended to challenge classifications and phylogenies by physical anthropologists and evolutionary biologists, the molecular analyses presented at the Cambridge conference supported one of two models of modern human origins dominant in paleoanthropology and prehistoric archeology. Molecular anthropology corroborated the tenets of the out-of-Africa model: Africa had been the cradle of modern humans, since the molecules suggested a major African-Eurasian/African divide; modern humans had evolved relatively recently, as suggested by the molecular clock (regular fixation of neutral mutations); and human "racial" divergence was an even more recent phenomenon, since genetic variation within human populations was shown to be greater than between. ${ }^{100}$ Proponents of the out-ofAfrica model of modern human origins, among these the editors of The Human Revolution volume, therefore welcomed molecular anthropology as an ally against rival theories.

Furthermore, the out-of-Africa model of modern human origins was part of larger trends in physical anthropology that led to greater convergence with claims about hominoid phylogeny and evolution that had come out of the molecular biology labs. There were developments in theoretical orientations (punctuated equilibria hypothesis), methods (cladistics), and technologies (ESR, TL, U-series dating). These led to critiques of the hominoid phylogenies with little taxonomic diversity but relatively long linear lines of descent that had become dominant in anthropology through its integration into the modern synthesis. ${ }^{101}$ The new trends emphasized episodic evolutionary events and cladogenesis. The situation had also changed due to the discovery of new fossils, and due to the demise of others as possible oldest known near/hominids. Ramapithecus was by now seen as closer to the orangutan than to the hominid line. ${ }^{102}$

100 See for example Rouhani, 1989.

101 See for example Tattersall and Eldredge, 1977; Tattersall, 1995, in particular Chaps. 12 and 16. On the impact of cladistics on hominid taxonomy and its differences to adaptationism see Cartmill, 2001; Delisle, 2001.

102 The discovery of facial remains of the close Ramapithecus-relative, Sivapithecus, in $1979 / 1980$, suggested to paleoanthropologists that the taxa were allied with the orangutan rather than with hominids (see Lewin, 1984, p. 1182, and Lewin, 1997 (1987), Chaps. 5 and 6; for a historical overview of developments in hominoid phylogeny and taxonomy, see Schwartz, 2001; for a discussion of the recent human origins model, its support from paleoanthropology, archeology, and molecular anthropology, as well its cultural resonance with positive connotations of multiculturalism see Proctor, 2003). 
However, the results from molecular anthropology remained hotly debated. No longer did the matter of when the hominid line split from the anthropoid line(s) take center stage. Instead the question of how far back in history "the human races" could be traced was controversial. In his contribution to the conference volume, the anthropologist Milford Wolpoff (University of Michigan) pointed at the difficulties of the Recent African Evolution theory. He criticized Cann and her colleagues for basing their molecular reconstruction of modern human origins on the assumption of a too high mtDNA divergence rate. Using the same mutation rate to calculate the point of anthropoid-hominid divergence, the human and chimpanzee lineages would have split as recently as about two million years ago, when australopithecines had long since evolved. Numbers attained on the basis of a lower mutation rate seemed more likely. These also corresponded with results from DNA hybridization and estimates from paleontology that ranged between five and eight million years for the anthropoid-hominid split. ${ }^{103}$ As a proponent of the so-called multiregional evolution scenario, Wolpoff wanted to make the point that rather than human "racial" divergence being as recent as to coincide with Homo sapiens, the process had begun earlier, in the aftermath of the supposedly first migrations out of Africa by Homo erectus. ${ }^{104}$

As Wolpoff's argumentation shows, the proponents of the multiregional as well was those of the out-of-Africa model of modern human origins saw their views supported by the fossil and archeological record as well as by some of the molecular studies. Both theories might therefore profit from the aura of objectivity surrounding the technologies, methods, and objects of molecular anthropology. At the same time, with questions of modern human origins and evolution taking center stage, the particularity of the anthropological gene and genome surfaced with unprecedented force. We have encountered the accusation of a special treatment of humans against those who maintained a greater taxonomic and phylogenetic distance between (African) apes and humans. Now that the controversy focused on the age of human "racial" diversity, the arguments involved mutual accusations of racism. This was spelled out by Wolpoff in the conference volume:

Finally, both Cann et al. (1987) and Gould (1987, 1988) have indicated that the Garden of Eden hypothesis [African Eve Theory]

${ }^{103}$ In general, although results from molecular anthropology on primate phylogeny and divergence times were much better received in the anthropological community than 25 years earlier, the controversies around the molecular clocks had far from subsided (see for example Gibbons, 1995; Lewin, 1985).

${ }^{104}$ Wolpoff, 1989. 
should be regarded as an important justification for accepting the reality of 'the underlying unity of all humans'. This is because the recent common-ancestry interpretation is said to be a means of showing that all human beings are closely related. But the contrary is not true, and the opposing hypothesis about multiregional human evolution does not support a different precept. In fact, quite the opposite. The interpretation of human evolution as a persistent shifting pattern of population contacts and shared ideas may provide an even stronger biological basis for accepting the unit of all humanity. The spread of humankind and its differentiation into distinct geographic groups that persisted through long periods of time, with evidence of long-lasting contact and cooperation, in many ways is a more satisfying interpretation of human prehistory than a scientific rendering of the story of Cain, based on one population quickly, and completely, and most likely violently, replacing all others. This rendering of modern population dispersals is a story of 'making war and not love', and if true its implications are not pleasant. ${ }^{105}$

As evidence from various fields was brought into convergence in competing accounts of modern human origins, the political fronts in negotiations over scientific turf, in which the anthropological gene and genome functioned as the source of powerful arguments, had changed. So had the most contested boundaries from those between human and non-human to those between the human "races." The different histories "read from" the anthropological gene and genome were those already available in paleoanthropology and prehistoric archeology, and they had their wider cultural foils. Once again, it was also a question of which story made for a more "satisfying" kind of history. In this case, the question revolved around which reading of the traces would suggest anthropological genes that had recorded origin stories of making love rather than of making war.

To conclude, in new relationships to paleoanthropology, molecular anthropology emerged with unprecedented power with respect to human phylogeny and evolutionary history in the 1980s. The molecular evidence was stronger than before not least because new technologies,

105 Wolpoff, 1989, p. 98. That the out-of-Africa scenario with a human "racial" history of less than 50,000 years can nonetheless be combined with the belief in significant differences between "the races" (morphologically, behaviorally, and mentally, but not genetically speaking) is exemplified by Sarich and Miele, 2004, particularly Chaps. 7-8. Sarich and Frank Miele reaffirm the notion of a brain size-intelligence link that in their view establishes a hierarchy from African to White to Asian. 
themselves immersed in a discourse of the objectivity of instruments and numbers, allowed to finally access the genes as linear sense carrying units. In the wake of DNA-hybridization research, DNA sequencing had extended and sequences were becoming much more widely available. ${ }^{106}$ The dream of directly extracting from anthropological genes and genomes the human history that had long since been inscribed into the semantides had come true. At the same time, despite new alliances, technologies, and objects, molecular anthropology had not resolved its controversies. These continued around the topics of mutation rates, the selective neutrality of mutations, the best method of molecular comparison (genetic distance analysis versus sequencing), and the treebuilding methods (maximum parsimony or alternative method). As in the past, however, these issues could not dash the hopes put into the molecular approach:

[...] there are good grounds for thinking that continued research into the detailed patterns of genetic variability in modern populations (based, for example, on larger samples, and on more precisely controlled estimates of genetic mutation rates) will provide a firm answer to many if not all of these issues over the course of the next few years. ${ }^{107}$

And, "[i]t seems likely that within a few years it will be possible to study population migrations with a battery of population specific polymorphisms." 108

\section{The Anthropological Gene and Genome Revisited}

As so many of the optimistic prophecies we have encountered in the course of this article, the one with which I ended the last section has come true. This has been helped on by the development and marketing of automated DNA multiplication (PCR) and automated DNA sequencing machines in the second half of the 1980s. The entire human genome has been sequenced in the HGP, and human "racial" variation and evolution have been studied by a "battery of population specific markers" in a number of projects. Finally, successes have been made

\footnotetext{
106 On the history of DNA hybridization work see Schwartz, 2005, pp. 8-11; Schwartz and Maresca, 2006, pp. 5-7.

107 Mellars and Stringer, 1989, p. 5.

108 Wainscoat et al., 1989, p. 37.
} 
with the extraction of DNA from ancient tissues. ${ }^{109}$ In the process, the notion of DNA sequences as encoding the secrets of our humanness has prevailed. So has their position as the key to our individual and group identity in relation to other individuals and groups today, and in the context of the evolutionary past.

Why is this so? The episodic history of molecular anthropology as outlined above suggests that for the extrapolation of phylogenetic information, the sequences of amino acids (as gene proxies) and of deoxy/ribonucleic acids have been and have remained of epistemic value. Rather than at higher levels of organismal complexity, information about evolutionary relationships between organisms was and is seen to reside in sequence differences, that is at the most basic level of molecular analysis. The complexity of "the genome" and "the gene" as already an issue in the 1960s was therefore of concern in molecular systematics in so far as it was deemed relevant for the history of sequence structures. This concern surfaced in the debates about the influence of natural selection at the sequence level. With notions such as primary crypticity and the neutral theory of evolution at the molecular level, this concern was further reduced. Sequences were seen to store evolutionary history most directly, exactly where they were considered only loosely related to the phenotype. It is in this sense that they most accurately documented evolutionary transmission and stochastic change. Eventually, with the knowledge of the vast amount of non-genic and non-coding DNA, the gene itself seems to have been lost in a genomic sea. As the anthropologist Jonathan Marks puts it: "Genes are unique in that they happen to be directly responsible of what we observe as phenotypes, but in their milieu they are just more DNA." 110

The conception of DNA sequences as the most authentic archives of phylogeny and evolution was linked to the situation that as newcomers to a territory already occupied by other scientific fields such as paleoanthropology and evolutionary biology, those interested in molecular anthropology emphasized the difference of their approach. In contrast to the higher level of establishing phylogeny by morphological comparisons of living and fossil organisms, they were looking at the most fundamental level of life. The semantides, and in particular DNA sequences, have been proclaimed as the most basic, direct, and least environmentally

109 These developments largely took off in the mid-1980s (for an expression of the1980s DNA-hype see Lewin, 1984; the Human Genome Project resulted mainly from initiatives taken in the mid-1980s (see Kevles, 1992); statistical analysis of human genetic variation also became feasible around this time (see for example Reardon, 2001, p. 360); for early successes in ancient DNA cloning see Pääbo, 1985).

110 Marks, 1995, p. 141. 
distorted records of phylogeny and evolution. This led to a paradox, when an object allegedly free from ontogenetic contam ination, a near metrical device for the measurement of evolutionary time, was presented as storing a semantic kind of information. The semantides as documents of evolutionary history may be viewed as precursors of the notion of the gene or genome as document of evolutionary history in the sense used by Jones and Relethford. Molecular data like those generated by Cann, Stoneking and Wilson are translated into stories that include historical events such as the time and place of modern human origin(s), population migrations, encounters, and differentiation. The idea that this kind of narrative information could be archived in DNA, however, seems to contradict the claim of a molecular clock independent from higher level events that allows translating unit differences into degrees of relatedness and phylogenetic divergence times in the first place.

The paradox of the anthropological gene, too, is related to molecular anthropology's position vis-à-vis the traditional ways of reconstructing human phylogeny and evolution. Drawing on the common knowledge about the historical and cultural shaping of practices and ideas in physical anthropology, molecular anthropologists at times promoted their approach as value-free, as driven by logic, mathematics, and technology. Rather than being subject to the anthropologist's political stance towards what it means to be human and towards human diversity, molecular anthropology was presented as a set of methods and technologies that simply made visible the natural order of the primates. Put sharply, according to this view, molecular anthropological studies were not subject to translation and interpretation processes. They resembled more the physical sciences, because they dealt with quantitative comparisons between sequences in molecules that could be shown to stand in a more or less constant relation to linear time. But, in particular in new alliances with paleoanthropology and prehistoric archeology, the supposedly valueneutral and quantitative science became entangled in discussions about racism with regard to different scenarios of modern human evolution.

In the aftermath of the Cambridge conference discussed in the previous section, even though eventually with qualified success, the HGP has continued the rhetoric of our DNA as the constitutive material of our life as humans: "There is no more basic or more fundamental information that could be available."111 However, although the discourses around the HGP overlapped with those we met with in molecular anthropology, the two have to be kept apart. The HGP did not have as its aim to unravel the genomic differences between humans

111 Gilbert, 1992, p. 84. 
and other primates or between human groups, but explicitly to construct a universally human genome to tackle medical questions on the molecular level. In fact, chromosomes of different individuals were morphed into the universal (male) genome. Following its rhetoric, the HGP was after "the underlying human structure" to "reflect our common humanity." 112 Because it was targeted at more complex issues than DNA sequences (which were merely seen as a tool to higher ends), the HGP had difficulties achieving its promises.

Ironically, the same might not have been true for the Human Genome Diversity Project, because, as we have seen, molecular systematics may not be concerned with higher-level phenomena. The HGDP would have served the aims of molecular anthropology. Conceptualizing indigenous populations as historical isolates, it aimed at the preservation of endangered genetic information about phylogeny and evolutionary history. On the basis of the genetic variation collected in gene banks, scientists should be enabled to reconstruct the history of population migrations. Not surprisingly then, the HGDP has been associated with the epistemological privileging of molecular, particularly genetic, information, and has been involved in struggles over authority with other scientific fields such as paleoanthropology. It has also been entangled with historical and current political issues of "race," racism, and notions of purity that contradict the premise of the neutrality of the molecular approach. ${ }^{113}$

There are several projects that follow in the footsteps of the HGDP, such as the HapMap, the Genographic, and the African Ancestry projects, and national genetic projects such as Irish Origins. Some of these projects couple population genetics with the market for genealogical research. ${ }^{114}$ They ride on the boom of lay genealogical interest and the authority of genetics with regard to human identity. Companies advertise DNA analyses as means to unravel family genealogy, membership in current and prehistoric ethnic or tribal groups, and the place of one's DNA in the human family tree at large (for example, Family Tree DNA (associated with the Genographic Project), DNAPrint

112 Gilbert, 1992, p. 96. The first complete human sequence was intended to be a composite being, having both $\mathrm{X}$ and $\mathrm{Y}$, and stemming from DNA of people from the United States, the European countries, and Japan; it would be a multinational and multiracial second Adam (see Kevles, 1992, pp. 18-36).

113 Reardon, 2005; the literature on the HGP and the HGDP is considerable, see for example also Haraway, 1997, pp. 244-254; Kevles and Hood, 1992; Marks, 2001.

114 On the Genographic Project see Nash, 2007; on the African Ancestry project see Winston and Kittles, 2005; on the Irish Origins project see Nash, 2006; on general issues related to current population genetical projects see also Marks, 2001, 2005. 
Genomics, Genelex, GeneTree, Orchid Cellmark, Oxford Ancestors, and Relative Genetics ${ }^{\mathrm{TM}}$ ). ${ }^{115}$ Relethford's words quoted at the beginning of this paper could appear on the website of many of the U.S., Canadian, and British companies that offer genetic ancestry tracing, as exemplified by the founder and scientific director of African Ancestry Inc.: "Science and technology now provides a bridge to the past. Technological advances in DNA technology now open up new and unprecedented opportunities for African Americans to fill centuries old voids in knowledge of their family history."

Again, DNA technology is presented as providing access to a historical archive that is more complete than oral or written history. As in the case of Relethford, the comparison often involves a transition from personal history to the prehistory of humankind without expounding the associated epistemological problems. We are then no longer considering the search for parents, grandparents, great grandparents, and so forth, but for population migrations and interactions, and finally for the grand picture of human history, reflections of our past. However, as discussed in this article, the information extracted from DNA sequences is not a simple completion and extension of family history, nor does it unambiguously relate to any other kind of narrative history. African Ancestry Inc. knows and offers a book with historical and cultural references for twenty-one African countries with its test kit and products order form. Narratives need to be inscribed into deoxyribonucleic acid after all.

\section{References}

Abir-Am, Pnina G. 1992. "The Politics of Macromolecules. Molecular Biologists, Biochemists, and Rhetoric." Osiris, 2nd Series 7 (Science after '40): 164-191.

Aronson, Jay D. 2002. "Molecules and Monkeys'. George Gaylord Simpson and the Challenge of Molecular Evolution." History and Philosophy of the Life Sciences 24: 441-465.

115 On Oxford Ancestors see Sommer, 2007, Chap. 16. Its service MatriLine ${ }^{\mathrm{TM}}$ informs customers about their own maternal ancestry and their place in the family tree of all humanity, whereas the Y-Clan ${ }^{\mathrm{TM}}$ and the Tribes of Britain ${ }^{\mathrm{TM}}$ services provide male customers with information about paternal ancestry. Obviously, Tribes of Britain ${ }^{\mathrm{TM}}$ works only for men of British ancestry, and is supposed to determine Celtic, AngloSaxon/Danish Viking, or Norse Viking ancestry. Customers wishing an mtDNA analysis for $£ 180$ will receive, apart from a readout of 400 base pairs of their mitochondrial chromosome, a certificate that indicates to which of the clans of "the seven daughters of Eve" they belong, that is from which of seven postulated European female lines they have supposedly descended (see also Nash, 2004, 2005).

116 Winston and Kittles, 2005, p. 222 (on genetic ancestry tracing services tailored to (prospective) Native Americans see TallBear, 2007). 
Brown, W. M. 1980. "Polymorphism in Mitochondrial DNA of Humans as Revealed by Restriction Endonuclease Analysis." Proceedings of the National Academy of Sciences 77: 3605-3609.

Brown, W. M., George, M. and Wilson, A. C. 1979. "Rapid Evolution of Mitochondrial DNA." Proceedings of the National Academy of Science 76: 1967-1971.

Cann, Rebecca L. 1988. "DNA and Human Origins." Annual Review of Anthropology 17: $127-143$.

1997. "Mothers, Labels, and Misogyny." Lori D. Hager (ed.), Women in Human Evolution. London: Routledge.

Cann, Rebecca L., Stoneking, Mark and Wilson, Allan C. 1987. "Mitochondrial DNA and Human Evolution." Nature 325: 32-36.

Cartmill, Matt. 2001. "Taxonomic Revolutions and the Animal-Human Boundary." Raymond Corbey and Wil Roebroeks (eds.), Studying Human Origins. Disciplinary History and Epistemology. Amsterdam: Amsterdam University Press.

Cavalli-Sforza, Luca L. and Edwards, A. W. F. 1967. "Phylogenetic Analysis. Models and Estimation Procedures." American Journal of Human Genetics 23: 235-252.

de Chadarevian, Soraya. 2002. Designs for Life. Molecular Biology after World War II. Cambridge: Cambridge University Press.

Creager, Angela N. H. 1996. "Wendell Stanley's Dream of a Free-Standing Biochemistry Department at the University of California, Berkeley." Journal of the History of Biology 29: 331-360.

Delisle, Richard G. 2001. "Adaptationism Versus Cladism in Human Evolution Studies." Raymond Corbey and Wil Roebroeks (eds.), Studying Human Origins. Disciplinary History and Epistemology. Amsterdam: Amsterdam University Press.

Dene, Howard T., Goodman, Morris and Prychodko, William. 1976. "Immunodiffusion Evidence on the Phylogeny of the Primates." Morris Goodman, Richard E. Tashian and Jeanne H. Tashian (eds.), Molecular Anthropology. Genes and Proteins in the Evolutionary Ascent of the Primates. New York: Plenum.

Dietrich, Michael R. 1994. "The Origins of the Neutral Theory of Molecular Evolution." Journal of the History of Biology 27(1): 21-59.

— 1998. "Paradox and Persuasion. Negotiating the Place of Molecular Evolution within Evolutionary Biology." Journal of the History of Biology 31: 85-111.

2000. "The Problem of the Gene." Comptes Rendus de l'Academie des Sciences Paris, Sciences de la vie/Life Sciences 323: 1139-1146.

Dobzhansky, Theodosius. 1963. "Genetic Entities in Hominid Evolution." Sherwood

L. Washburn (ed.), Classification and Human Evolution. Chicago: Aldine.

— 1964. "Biology, Molecular and Organismic." American Zoologist 4: 443-452.

1966. “Are Naturalists Old-Fashioned?” The American Naturalist 100 (915, Special One Hundredth Anniversary Year Issue): 541-550.

Dobzhansky, Theodosius and Boesiger, Ernest. 1983. Human Culture. A Moment in Evolution (edited and completed by Bruce Wallace). New York: Columbia University Press.

Fitch, Walter M. 1982. "The Challenges to Darwinism Since the Last Centennial and the Impact of Molecular Studies." Evolution 36(6): 1133-1143.

Fitch, Walter M. and Langley, Charles H. 1976. "Evolutionary Rates in Proteins: Neutral Mutations and the Molecular Clock." Morris Goodman, Richard E. Tashian and Jeanne H. Tashian (eds.), Molecular Anthropology. Genes and Proteins in the Evolutionary Ascent of the Primates. New York: Plenum. 
Gannett, Lisa. 2001. "Racism and Human Genome Diversity Research. The Ethical Limits of 'Population Thinking'." Philosophy of Science. Supplement: Proceedings of the 2000 Biennial Meeting of the Philosophy of Science Association. Part I: Contributed Papers 68(3): S479-S492.

Gatlin, Lila L. 1976. "Information Theory, Molecular Evolution, and the Concepts of von Neumann." Morris Goodman, Richard E. Tashian and Jeanne H. Tashian (eds.), Molecular Anthropology. Genes and Proteins in the Evolutionary Ascent of the Primates. New York: Plenum.

Gayon, Jean. 1998 (1992). Darwin's Struggle for Survival. Heredity and the Hypothesis of Natural Selection. Matthew Cobb (Trans.) Michael Ruse (ed.), Cambridge Studies in Philosophy and Biology. Cambridge: Cambridge University Press.

Gibbons, Ann. 1990. "Our Chimp Cousins Get That Much Closer." Science, New Series 250(4979): 376.

— 1995. "When It Comes to Evolution, Humans Are the Slow Class." Science, New Series 267(5206): 1907-1908.

Gilbert, Walter. 1992. "A Vision of the Grail.” Daniel J. Kevles and Leroy Hood (eds.), The Code of Codes. Scientific and Social Issues in the Human Genome Project. Cambridge: Harvard University Press.

Goodman, Morris. 1960. "The Species Specificity of Proteins as Observed in the Wilson Comparative Analyses Plates." American Naturalist 94: 184-186.

- 1962. "Immunochemistry of the Primates and Primate Evolution." Annals of the New York Academy of Sciences 102: 219-234.

1963. "Man's Place in the Phylogeny of the Primates as Reflected in Serum Proteins." Sherwood L. Washburn (ed.), Classification and Human Evolution. Chicago: Aldine.

1976. "Toward a Genealogical Description of the Primates." Morris Goodman, Richard E. Tashian and Jeanne H. Tashian (eds.), Molecular Anthropology. Genes and Proteins in the Evolutionary Ascent of the Primates. New York: Plenum.

Goodman, Morris, Poulik, E. and Poulik, M. D. 1960. "Variations in the Serum Specificities of Higher Primates Detected by Two-Dimensional Starch-Gel Electrophoresis." Nature 188: 78-79.

Goodman, Morris, Tashian, Richard E. and Tashian, Jeanne H. 1976. "Progress in Molecular Anthropology." Current Anthropology 17(3): 491-494.

- (eds.). 1976. "Molecular Anthropology. Genes and Proteins in the Evolutionary Ascent of the Primates." W. Patrick Luckett and Charles R. Noback (eds.), Advances in Primatology. New York: Plenum.

Hagen, Joel B. 1999. "Naturalists, Molecular Biologists, and the Challenges of Molecular Evolution." Journal of the History of Biology 32: 321-341.

Haraway, Donna J. 1988. "Remodelling the Human Way of Life. Sherwood Washburn and the New Physical Anthropology, 1950-1980." George W. Stocking (ed.), Bones, Bodies, Behavior. Essays on Biological Anthropology. Wisconsin: The University of Wisconsin Press.

1997. Modest_Witness@SSecond_Millennium.FemaleMan@_Meets_OncoMouse ${ }^{T M}$, Feminism and Technoscience. New York: Routledge.

Haury, Emil W. 1963. “Axel L. Wenner-Gren, 1881-1961.” American Antiquity 29(1): 90-91.

Holmquist, Richard. 1976. "Random and Nonrandom Processes in the Molecular Evolution of Higher Organisms." Morris Goodman, Richard E. Tashian and 
Jeanne H. Tashian (eds.), Molecular Anthropology. Genes and Proteins in the Evolutionary Ascent of the Primates. New York: Plenum.

Jacob, F. and Monod, J. 1961. "On the Regulation of Gene Activity." Cold Spring Harbor Symposium of Quantitative Biology 26: 193-211.

Johannsen, W. 1911. "The Genotype Conception of Heredity." The American Naturalist 45(531): 129-159.

Jones, K. W. 1976. "Comparative Aspects of DNA in Higher Primates." Morris Goodman, Richard E. Tashian and Jeanne H. Tashian (eds.), Molecular Anthropology. Genes and Proteins in the Evolutionary Ascent of the Primates. New York: Plenum.

Judson, Horace Freeland. 1996 (1979). The Eighth Day of Creation. Makers of the Revolution in Biology, 2nd ed. Cold Spring Harbor: Cold Spring Harbor Laboratory Press.

1992. "A History of the Science and Technology Behind Gene Mapping and Sequencing." Daniel J. Kevles and Leroy Hood (eds.), The Code of Codes Scientific and Social Issues in the Human Genome Project. Cambridge: Harvard University Press.

Kay, Lily E. 1993. "The Molecular Vision of Life. Caltech, The Rockefeller Foundation, and the Rise of the New Biology." Richard Burian, Richard Burkhardt Jr., Richard Lewontin and John Maynard Smith (eds.), Monographs on the History and Philosophy of Biology. New York: Oxford University Press.

- 1994. "Wer schrieb das Buch des Lebens? Information und Transformation der Molekularbiologie." Michael Hagner, Hans-Jörg Rheinberger and Bettina WahrigSchmidt (eds.), Objekte, Differenzen und Konjunkturen. Experimentalsysteme im historischen Kontext. Berlin: Akademie Verlag.

- 2000. "Who Wrote the Book of Life? A History of the Genetic Code." Timothy Lenoir and Hans Ulrich Gumbrecht (eds.), Writing Science. Stanford: Stanford University Press.

Keller, Evelyn Fox. 1992. "Nature, Nurture, and the Human Genome Project." Daniel J. Kevles and Leroy Hood (eds.), The Code of Codes. Scientific and Social Issues in the Human Genome Project. Cambridge: Harvard University Press.

2000. The Century of the Gene. Cambridge: Harvard University Press.

Kevles, Daniel J. 1992. "Out of Eugenics. The Historical Politics of the Human Genome." Daniel J. Kevles and Leroy Hood (eds.), The Code of Codes. Scientific and Social Issues in the Human Genome Project. Cambridge: Harvard University Press.

Kevles, Daniel J. and Hood, Leroy (eds.). 1992. The Code of Codes. Scientific and Social Issues in the Human Genome Project. Cambridge: Harvard University Press.

Kimura, Motoo. 1968. "Evolutionary Rate at the Molecular Level." Nature 217: 624 626.

King, Jack Lester and Jukes, Thomas H. 1969. "Non-Darwinian Evolution.” Science 164: 788-798.

Klinger, Harold P., Hamerton, John L., Mutton, David and Lang, Ernst M. 1963. "The Chromosomes of the Hominoidea." Sherwood L. Washburn (ed.), Classification and Human Evolution. Chicago: Aldine.

Lasker, Gabriel W. 1976. "What Is Molecular Anthropology?" Morris Goodman, Richard E. Tashian and Jeanne H. Tashian (eds.), Molecular Anthropology. Genes and Proteins in the Evolutionary Ascent of the Primates. New York: Plenum.

Lewin, Roger. 1984. "DNA Reveals Surprises in Human Family Tree." Science, New Series 226(4679): 1179-1182. 
1985. "Molecular Clocks Scrutinized.” Science, New Series 228(4699): 571.

1988a. "Conflict Over DNA Clock." Science, New Series 241(4873): 1598-1600. 1988b. "DNA Clock Conflict Continues." Science, New Series 4874: 1756-1759. 1997 (1987). Bones of Contention. Controversies in the Search for Human Origins, 2nd ed. Chicago: The University of Chicago Press.

Livingstone, Frank B. 1962. "On the Non-Existence of Human Races." Current Anthropology 3: 279-281.

Lucotte, G. 1989. "Evidence for the Paternal Ancestry of Modern Humans. Evidence From a Y-Chromosome Specific Sequence Polymorphic DNA Probe." Paul Mellars and Chris Stringer (eds.), The Human Revolution. Behavioural and Biological Perspectives on the Origins of Modern Humans. Edinburgh: Edinburgh University Press.

Marks, Jonathan. 1995. "Human Biodiversity. Genes, Race, and History." Monique Borgerhoff Mulder and Marc Hauser (eds.), Evolutionary Foundations of Human Behavior. New York: Aldine de Gruyter.

- 2001. "We're Going to Tell These People Who They Really Are': Science and Relatedness." Sarah Franklin and Susan McKinnon (eds.), Relative Values. Reconfiguring Kinship Studies. Durham: Duke University Press.

- 2005. "Your Body, My Property: The Problem of Colonial Genetics in a Postcolonial World." Lynn Meskell and Peter Pels (eds.), Embedding Ethics. Oxford: Berg.

Matsuda, Genji. 1976. "Evolution of the Primary Structures of Primate and Other Vertebrate Hemoglobins." Morris Goodman, Richard E. Tashian and Jeanne H. Tashian (eds.), Molecular Anthropology. Genes and Proteins in the Evolutionary Ascent of the Primates. New York: Plenum.

Mayr, Ernst. 1961. "Cause and Effect in Biology." Science, New Series 134(3489): 15011506.

_ 1963a. "The New versus the Classical in Science." Science, New Series 141(3583): 765.

— 1963b. "The Taxonomic Evaluation of Fossil Hominids." Sherwood L. Washburn (ed.), Classification and Human Evolution. Chicago: Aldine.

McNally, Ruth and Glasner, Peter. 2007. "Survival of the Gene?." Paul Atkinson, Peter Glasner and Helen Greenslade (eds.), New Genetics, New Identities. London: Routledge.

Mellars, Paul and Stringer, Chris (eds.). 1989. The Human Revolution. Behavioural and Biological Perspectives on the Origins of Modern Humans. Edinburgh: Edinburgh University Press.

Moore, William G. 1976. "Proof of the Maximum Parsimony ('Red King') Algorithm." Morris Goodman, Richard E. Tashian and Jeanne H. Tashian (eds.), Molecular Anthropology. Genes and Proteins in the Evolutionary Ascent of the Primates. New York: Plenum.

Morgan, Gregory J. 1998. "Emile Zuckerkandl, Linus Pauling, and the Molecular Evolutionary Clock, 1959-1965." Journal of the History of Biology 31: 155-178.

Nash, Catherine. 2004. "Genetic Kinship." Cultural Studies 18(1): 1-33.

— 2005. "Geographies of Relatedness." Transactions of the Institute for British Geographers 30: 449-462.

2006. "Irish Origins, Celtic Origins. Population Genetics, Cultural Politics." Irish Studies Review 14(1): 11-37. 
2007. "Mapping Origins. Race and Relatedness in Population Genetics and Genetic Genealogy." Paul Atkinson, Peter Glasner and Helen Greenslade (eds.), New Genetics, New Identities. London: Routledge.

Nirenberg, M. W. and Matthaei, J. H. 1962. "The Dependence of Cell-Free Protein Synthesis in Escherichia coli upon Naturally Occurring or Synthetic Polyribonucleotides." Proceedings of the National Academy of Science 47: 1588-1602.

Nuttall, George H. 1904. Blood Immunity and Blood Relationship. Cambridge: Cambridge University Press.

Olby, Robert. 1994 (1974). The Path to the Double Helix. The Discovery of DNA, 2nd ed. New York: Dover.

Pääbo, Svante. 1985. "Molecular Cloning of Ancient Egyptian Mummy DNA." Nature 314: 644-645.

Pauling, Linus and Zuckerkandl, Emile. 1963. "Chemical Paleogenetics. Molecular 'Restoration Studies' of Extinct Forms of Life." Acta Chemica Scandinavica 17(Suppl. 1): 9-16.

Portin, Petter. 1993. "The Concept of the Gene. Short History and Present Status." The Quarterly Review of Biology 68(2): 173-223.

Proctor, Robert. 2003. "Three Roots of Human Recency. Molecular Anthropology, the Refigured Acheulean, and the UNESCO Response to Auschwitz." Current Anthropology 44(2): 213-239.

Reardon, Jenny. 2001. "The Human Genome Diversity Project. A Case Study in Coproduction." Social Studies of Science 31(3): 357-388.

_ 2005. "Race to the Finish. Identity and Governance in an Age of Genomics." Paul Rabinow (ed.), Information Series. Princeton: Princeton University Press.

Relethford, John H. 2003. Reflections of Our Past. How Human History is Revealed in Our Genes. Boulder: Westview.

Rheinberger, Hans-Jörg. 1995. "Eine kurze Geschichte der Molekularbiologie." MaxPlanck-Institute für Wissenschaftsgeschichte Preprint 24.

Rheinberger, Hans-Jörg and Müller-Wille, Staffan. 26, October 2004. "Gene.” Edward N. Zalta (ed.), The Stanford Encyclopedia of Philosophy. http://www.plato.stanford.edu/.

Romero-Herrera, A. E., Lehmann, H., Joysey, K. A. and Friday, A. E. 1976. "Evolution of Myoglobin Amino Acid Sequences in Primates and Other Vertebrates." Morris Goodman, Richard E. Tashian and Jeanne H. Tashian (eds.), Molecular Anthropology. Genes and Proteins in the Evolutionary Ascent of the Primates. New York: Plenum.

Rouhani, Shahin. 1989. "Molecular Genetics and the Pattern of Human Evolution. Plausible and Implausible Models." Paul Mellars and Chris Stringer (eds.), The Human Revolution. Behavioural and Biological Perspectives on the Origins of Modern Humans. Edinburgh: Edinburgh University Press.

Sarich, Vincent M. 1969. "Pinniped Phylogeny." Systematic Zoology 18(4): 416-422. 1971. "A Molecular Approach to the Question of Human Origins." Phyllis Dolhinow and Vincent Sarich (eds.), Background for Man. Readings in Physical Anthropology. Boston: Little, Brown and Company.

Sarich, Vincent M. and Cronin, John E. 1976. "Molecular Systematics of the Primates." Morris Goodman, Richard E. Tashian and Jeanne H. Tashian (eds.), Molecular Anthropology. Genes and Proteins in the Evolutionary Ascent of the Primates. New York: Plenum.

Sarich, Vincent M. and Miele, Frank. 2004. Race. The Reality of Human Differences. Boulder: Westview. 
Sarich, Vincent M. and Wilson, Allan C. 1967. "Immunological Time Scale of Hominid Evolution." Science, New Series 158(3805): 1200-1203.

Schultz, Adolph H. 1963. "Age Changes, Sex Differences, and Variability as Factors in the Classification of Primates." Sherwood L. Washburn (ed.), Classification and Human Evolution. Chicago: Aldine.

Schwartz, Jeffrey H. 2001. "A Review of the Systematics and Taxonomy of Hominoidea. History, Morphology, Molecules, and Fossils." Ludus Vitalis 9(15): 15-45.

2005. "Systematics and Evolution." R. A. Meyer (ed.), Encyclopedia of Molecular Cell Biology and Molecular Medicine (EMCBMM). Weinheim: Wiley-VCH.

Schwartz, Jeffrey H. and Maresca, Bruno. 2006. "Do Molecular Clocks Run at All? A Critique of Molecular Systematics." Biological Theory 1(4): 1-15.

Simons, Elwyn L. 1976. "The Fossil Record of Primate Phylogeny." Morris Goodman, Richard E. Tashian and Jeanne H. Tashian (eds.), Molecular Anthropology. Genes and Proteins in the Evolutionary Ascent of the Primates. New York: Plenum.

Simpson, George Gaylord. 1963. "The Meaning of Taxonomic Statements." Sherwood

L. Washburn (ed.), Classification and Human Evolution. Chicago: Aldine. 1964 (1963). "The Historical Factor in Science." This View of Life. The World of an Evolutionist. New York: Harcourt, Brace \& World.

- 1964. "Organisms and Molecules in Evolution." Science, New Series 146(3651): $1535-1538$.

-1964, 1966, 1967, 1969. Biology and Man. New York: Harcourt Brace Jovanovich. 1966a. "The Biological Nature of Man." Science, New Series 152(3721): 472-478. 1966b. "Interpretations of DNA." Science, New Series 154(3753): 1120.

Sommer, Marianne. 2007. Bones and Ochre. The Curious Afterlife of the Red Lady of Paviland. Cambridge: Harvard University Press.

- forthcoming. "Von der Abstammung zum Fortschritt. Die Ausnahme Mensch in der Evolutionären Synthese.".

Spencer, Frank. 1982. "Introduction." Frank Spencer (ed.), A History of American Physical Anthropology 1930-1980. New York: Academic Press.

Stoneking, Mark and Cann, Rebecca. 1989. "African Origin of Human Mitochondrial DNA." Paul Mellars and Chris Stringer (eds.), The Human Revolution. Behavioural and Biological Perspectives on the Origins of Modern Humans. Edinburgh: Edinburgh University Press.

Stotz, Karola, Griffiths, Paul E. and Knight, Rob. 2004. "How Biologists Conceptualize Genes. An Empirical Study." Studies in History and Philosophy of Science Part C: Studies in History and Philosophy of Biological and Biomedical Sciences 35(4): 647-673.

Suárez, Edna. 2001. "Satellite-DNA. A Case-Study for the Evolution of Experimental Techniques." Studies in History and Philosophy of Biological and Biomedical Sciences 32(1): 31-57.

2007. "The Rhetoric of Informational Molecules. Authority and Promises in the Early Study of Molecular Evolution." Science in Context 20(4): 1-29.

Suárez, Edna and Barahona, Ana. 1996. "The Experimental Roots of the Neutral Theory of Molecular Evolution." History and Philosophy of the Life Sciences 18: 55-81.

TallBear, Kimberly. 2007 "Native-American-DNA.coms. In Search of Native American Race and Tribe." Barbara Koenig, Sandra Soo-Jin Lee and Sarah Richardson (eds.), Revisiting Race in a Genomic Age. New Brunswick: Rutgers University Press. 
Tashian, Richard E., Goodman, Morris, Ferrell, Robert E. and Tanis, Robert J. 1976. "Evolution of Carbonic Anhydrase in Primates and Other Mammals." Morris Goodman, Richard E. Tashian and Jeanne H. Tashian (eds.), Molecular Anthropology. Genes and Proteins in the Evolutionary Ascent of the Primates. New York: Plenum.

Tattersall, Ian. 1995. The Fossil Trail. How We Know What We Think We Know about Human Evolution. New York: Oxford University Press.

Tattersall, Ian and Eldredge, Niles. 1977. "Fact, Theory, and Fantasy in Human Paleontology." American Scientist 65(March-April): 204-211.

"Toward Discovery by Communication: The New Conference Center at Burg Wartenstein." 1960. Current Anthropology 1(3): 255.

Uzzell, Thomas and Pilbeam, David. 1971. "Phyletic Divergence Dates of Hominoid Primates. A Comparison of Fossil and Molecular Data." Evolution 25(4): 615-635.

Vogel, F., Kopun, M. and Rathenberg, R. 1976. "Mutation and Molecular Evolution." Morris Goodman, Richard E. Tashian and Jeanne H. Tashian (eds.), Molecular Anthropology. Genes and Proteins in the Evolutionary Ascent of the Primates. New York: Plenum.

Wadsworth, Frank W. 1978. "Change in Wenner-Gren Foundation Conference Program." Current Anthropology 19(3): 654.

Wainscoat, J. S., Hill, A. V. S., Thein, S. L., Flint, J., Chapman, J. C., Weatherall, D. J., Clegg, J. B. and Higgs, D. R. 1989. "Geographic Distribution of Alpha- and BetaGlobin Gene Cluster Polymorphisms." Paul Mellars and Chris Stringer (eds.), The Human Revolution. Behavioural and Biological Perspectives on the Origins of Modern Humans. Edinburgh: Edinburgh University Press.

Walker, Alan. 1976. "Splitting Times Among Hominoids Deduced from the Fossil Record." Morris Goodman, Richard E. Tashian and Jeanne H. Tashian (eds.), Molecular Anthropology. Genes and Proteins in the Evolutionary Ascent of the Primates. New York: Plenum.

Washburn, Sherwood L. 1951. "The New Physical Anthropology." Transactions of the New York Academy of Sciences, 2nd Series 13: 298-304.

— 1952. "The Strategy of Physical Anthropology." A. L. Kroeber (ed.), Anthropology Today. Chicago: The University of Chicago Press.

— 1967. "Behaviour and the Origin of Man." Proceedings of the Royal Anthropological Institute of Great Britain and Ireland 1967: 21-27.

— 1982. "Fifty Years of Studies on Human Evolution." The Bulletin of the Atomic Scientists 38: 37-43.

- 1983. "Evolution of a Teacher." Annual Review of Anthropology 12: 1-12.

(ed.). 1961. Social Life of Early Man. Chicago: Aldine.

(ed.). 1963. Classification and Human Evolution. Sol Tax (ed.), Viking Fund Publications in Anthropology, Vol. 37. Chicago: Aldine.

Waters, Kenneth C. 2004. "What Concept Analysis Should Be (and why competing philosophical analyses of gene concepts cannot be tested by polling scientists)." Studies in History and Philosophy of the Life Science 26: 29-58.

Wilson, Allan C., Carlson, Steven S. and White, Thomas J. 1977. "Biochemical Evolution." Annual Review of Biochemistry 46: 573-639.

Winston, Cynthia E. and Kittles, Rick A. 2005. "Psychological and Ethical Issues Related to Identity and Inferring Ancestry of African Americans." Trudy R. Turner (ed.), Biological Anthropology and Ethics. From Repatriation to Genetic Identity. Albany: State University of New York Press. 
Wolpoff, Milford H. 1989. "Multiregional Evolution. The Fossil Alternative to Eden." Paul Mellars and Chris Stringer (eds.), The Human Revolution. Behavioural and Biological Perspectives on the Origins of Modern Humans. Edinburgh: Edinburgh University Press.

Yoxen, Edward. 1982. "Giving Life a New Meaning. The Rise of the Molecular Biology Establishment." Norbert Elias, Herminio Martins and Richard Whitley (eds.), Scientific Establishment and Hierarchies Dordrecht: Reidel.

Zuckerkandl, Emile. 1963. "Perspectives in Molecular Anthropology." Sherwood L. Washburn (ed.), Classification and Human Evolution. Chicago: Aldine.

1976. "Programs of Gene Action and Progressive Evolution." Morris Goodman, Richard E. Tashian and Jeanne H. Tashian (eds.), Molecular Anthropology. Genes and Proteins in the Evolutionary Ascent of the Primates. New York: Plenum.

1987. "On the Molecular Evolutionary Clock." Journal of Molecular Evolution 26: 34-46.

Zuckerkandl, E., Jones, R. T. and Pauling, L. 1960. "A Comparison of Animal Hemoglobins by Tryptic Peptide Pattern Analysis." Proceedings of the National Academy of Science 46: 1349-1360.

Zuckerkandl, Emile and Pauling, Linus. 1962. "Molecular Disease, Evolution, and Genetic Heterogeneity." M. Kasha and B. Pullman (eds.), Horizons in Biochemistry. New York: Academic Press.

1965a. "Evolutionary Divergence and Convergence in Proteins." V. Bryson and H. L. Vogel (eds.), Evolving Genes and Proteins. New York: Academic Press.

- 1965b. "Molecules as Documents of Evolutionary History." Journal of Theoretical Biology 8: 357-366. 